\title{
CALCULATION OF A WATER BUDGET AND DELINEATION OF CONTRIBUTING SOURCES TO DRAINFLOWS IN THE WESTERN SAN JOAQUIN VALLEY, CALIFORNIA
}

\author{
By John L. Fio
}

\section{U.S. GEOLOGICAL SURVEY}

Open-File Report 94-45

Prepared in cooperation with the

PANOCHE WATER DISTRICT and the

CALIFORNIA DEPARTMENT OF WATER RESOURCES 


\title{
U.S. DEPARTMENT OF THE INTERIOR \\ BRUCE BABBITT, Secretary
}

\author{
U.S. GEOLOGICAL SURVEY \\ GORDON P. EATON, Director
}

Any use of trade, product, or firm names in this publication is for descriptive purposes only and does not imply

endorsement by the U.S. Government.

For sale by the

U.S. Geological Survey

Earth Science Information Center

Open-File Reports Section

Box 25286, MS 517

Denver Federal Center

Denver, CO 80225

For additional information write to:

District Chief

U.S. Geological Survey

Federal Building, Room W-2233

2800 Cottage Way

Sacramento, CA 95825 


\title{
CONTENTS
}

\author{
Abstract 1 \\ Introduction 1 \\ Background 3 \\ Study area 3 \\ Description of the water budget 7 \\ Approach 8 \\ Water-level measurement 8 \\ Simulating ground-water flow $\mathbf{1 1}$ \\ Sources and sinks 11 \\ Calculating equivalent hydraulic conductivity $\mathbf{1 1}$ \\ Estimating ground-water flow paths and advective traveltimes 12 \\ Delineating contributing sources to drainflow 13 \\ Calculation of water budget 13 \\ Geohydrologic framework 13 \\ Regional geohydrology and irrigation practices 13 \\ Distribution of sediment texture 14 \\ Average hydraulic heads and depth to water 19 \\ Recharge measurements 19 \\ Drainflow measurements $\mathbf{2 3}$ \\ Specification of model input $\mathbf{2 5}$ \\ Model geometry 25 \\ Boundary conditions 25 \\ Bare-soil evaporation from theoretical considerations 26 \\ Drainflow conductance terms calculated with drain-lateral densities 26 \\ Equivalent hydraulic conductivity and model assessment 29 \\ Contributing sources to drainflow $\mathbf{3 1}$ \\ Sensitivity of the water budget components to simulated hydrologic conditions $\mathbf{3 5}$ \\ Reducing recharge to the saturated zone 35 \\ Increasing deep percolation with increased pumping 36 \\ Specification of drainflow conductance terms 36 \\ Summary and conclusions $\mathbf{3 7}$ \\ References cited 38
}

\section{FIGURES}

1-4. Maps showing:

1. Part of the western San Joaquin Valley and general area of study 2

2. Study area and boundaries of the flow model, regional model, and field model 4

3. Distribution of drain-lateral density $\mathbf{5}$

4. Installation dates of selected drainage systems in part of the western San Joaquin Valley 6

5. Section showing control volume and water-budget components in a part of a typical field in the western San Joaquin Valley 7

6,7. Maps showing:

6. Areal distribution of shallow observation wells, cluster sites, and geohydrologic sections in part of the western San Joaquin Valley 9

7. Topography in modeled area $\mathbf{1 0}$

8. Geohydrologic sections showing textural distribution of the upper 30 meters of sediment in geohydrologic sections $A-A^{\prime}, B-B^{\prime}$, and $C-C^{\prime} \quad 15$ 
9-11. Maps showing:

9. Fraction of coarse-grained sediment in the 0- to 12-meter depth interval 16

10. Fraction of coarse-grained sediment in the 12- to 21 -meter depth interval 17

11. Fraction of coarse-grained sediment in the 21- to 30-meter depth interval $\mathbf{1 8}$

12. Geohydrologic sections showing average hydraulic heads and altitude of the water table projected onto the $A-A^{\prime}, B-B^{\prime}$, and $C-C^{\prime}$ geohydrologic sections 20

13-19. Maps showing:

13. Average depth to the water table and approximate location of a regional ground-water divide 21

14. Subareas of the study area, based on average depth to the water table and drainage conditions 22

15. Areal distribution of on-farm drainflow from flowmeter and electrical power-consumption data $\mathbf{2 4}$

16. Model grid and boundary conditions and expanded view of grid in study area $\mathbf{2 6}$

17. Average depth to water in the wells perforated below the bottom model layer $\mathbf{2 8}$

18. Delineation of drainage systems that intercept mostly recharge to the saturated zone, lateral ground-water flow, and upward-moving deep percolation in part of the western San Joaquin Valley 33

19. Recharge areas contributing to lateral ground-water flow and downslope drainflow in part of the western San Joaquin Valley $\mathbf{3 4}$

\section{TABLES}

1. Recharge to the saturated zone for three subareas, calculated as the sum of water applied and effective precipitation less consumptive use $\mathbf{2 3}$

2. Simulated hydraulic heads, drainflow, and bare-soil evaporation using vertical model cell conductances calculated by geometric and harmonic averaging techniques and measured or estimated from field data $\mathbf{3 0}$

3. Annual water budget for three subareas $\mathbf{3 1}$

4. Annual water budget for subareas of the drainage systems 32

5. Simulated water budget for three subareas for conditions of zero recharge to the saturated zone 35

6. Simulated water budget for three subareas for conditions of increased deep percolation as a result of increased pumping 36

7. Model results using three distributions of drain conductance $\mathbf{3 7}$ 


\section{CONVERSION FACTORS AND VERTICAL DATUM}

\section{Conversion Factors}

\begin{tabular}{rcl}
\hline Multiply & By & To obtain \\
\hline cubic meter $\left(\mathrm{m}^{3}\right)$ & 35.31 & cubic foot \\
cubic meter per year $\left(\mathrm{m}^{3} / \mathrm{y}\right)$ & 264.2 & gallon per year \\
kilometer $(\mathrm{km})$ & 0.6214 & mile \\
meter $(\mathrm{m})$ & 3.281 & foot \\
meter per year $(\mathrm{m} / \mathrm{y})$ & 3.281 & foot per year \\
meter per square kilometer $\left(\mathrm{m} / \mathrm{km}^{2}\right)$ & 8.497 & foot per square mile \\
square kilometer $\left(\mathrm{km}^{2}\right)$ & 0.3861 & square mile \\
square meter $\left(\mathrm{m}^{2}\right)$ & 10.76 & square foot \\
square meter per year $\left(\mathrm{m}^{2} / \mathrm{y}\right)$ & 10.76 & square foot per year \\
\hline
\end{tabular}

Temperature is given in degrees Celsius $\left({ }^{\circ} \mathrm{C}\right)$, which can be converted to degrees Fahrenheit $\left({ }^{\circ} \mathrm{F}\right)$ by the following equation:

$$
{ }^{\circ} \mathrm{F}=1.8\left({ }^{\circ} \mathrm{C}\right)+32 .
$$

\section{Vertical Datum}

Sea Level: In this report, "sea level" refers to the National Geodetic Vertical Datum of 1929-a geodetic datum derived from a general adjustment of the first-order level nets of the United States and Canada, formerly called Sea Level Datum of 1929. 


\title{
CALCULATION OF A WATER BUDGET AND DELINEATION OF CONTRIBUTING SOURCES TO DRAINFLOWS IN THE WESTERN SAN JOAQUIN VALLEY, CALIFORNIA
}

\author{
By John L. Fio
}

\begin{abstract}
Geohydrologic data and a ground-water flow model were used to calculate a water budget and evaluate the contribution of regional groundwater flow to on-farm drainflow in a part of the western San Joaquin Valley, California. Regional ground-water flow is affected by the distribution of unconsolidated coarse- and fine-grained sediment. Predominantly coarse-grained sediment in the upslope areas results in a water table greater than 3 meters below land surface, but the low-lying areas are underlain by predominantly fine-grained sediments and have a water table within 3 meters of land surface. The vertical component of flow is downward in the upslope areas, but can be upward at some locations in the low-lying areas.
\end{abstract}

Results of model simulations indicate that about $18.5 \times 10^{6}$ cubic meters per year of drainflow originates as recharge within the fields that overlay the drainage systems ( 89 percent), and $2.3 \times 10^{6}$ cubic meters per year of drainflow is lateral-flowing ground water and upward-moving deep percolation originating as recharge within fields upslope of the drainage systems (11 percent). The drainage systems that intercept this upslope recharge overlay predominantly coarsegrained sediment associated with old stream channels. This ground water can move upward from depths greater than 29 meters below land surface and distances as great as 3.6 kilometers, requiring from 10 to more than 90 years to reach the drainage systems.

\section{INTRODUCTION}

Salinity and drainage problems are common to irrigated agriculture in many arid regions of the world. As early as 1958 , growers in the western San Joaquin Valley of California began installing subsurface drainage systems to manage a shallow water table and soil salinity. Interest in the water-quality aspects of drainflows followed the discovery of high concentrations of selenium in drainwater (Deverel and others, 1984; Presser and Barnes, 1985) and its detrimental effects on local waterfowl populations (Ohlendorf and others, 1986). Results of previous studies suggest that a part of the drainflow originates as irrigation water applied to areas upslope of the drainage systems (Ayars and Schrale, 1989; Fio and Deverel, 1991; Leighton and others, 1992), hence managers attempting to reduce selenium loads in drainwater require quantitative information on the interaction between on-farm drainage systems and the regional ground-water flow system.

This report, the result of a study done by the U.S. Geological Survey (USGS) in cooperation with the Panoche Water District and the California Department of Water Resources, describes a balance of water additions and subtractions (a water budget) calculated from geohydrologic data and simulations made with a ground-water flow model of a part of the western San Joaquin Valley (fig. 1). A water-budget approach that includes a ground-water flow component was used to evaluate the contribution of regional groundwater flow to on-farm drainflow. Because the contribution of ground water to drainflow can be spatially variable, it is difficult to delineate the upslope areas that contribute recharge to downslope drainflow. For 


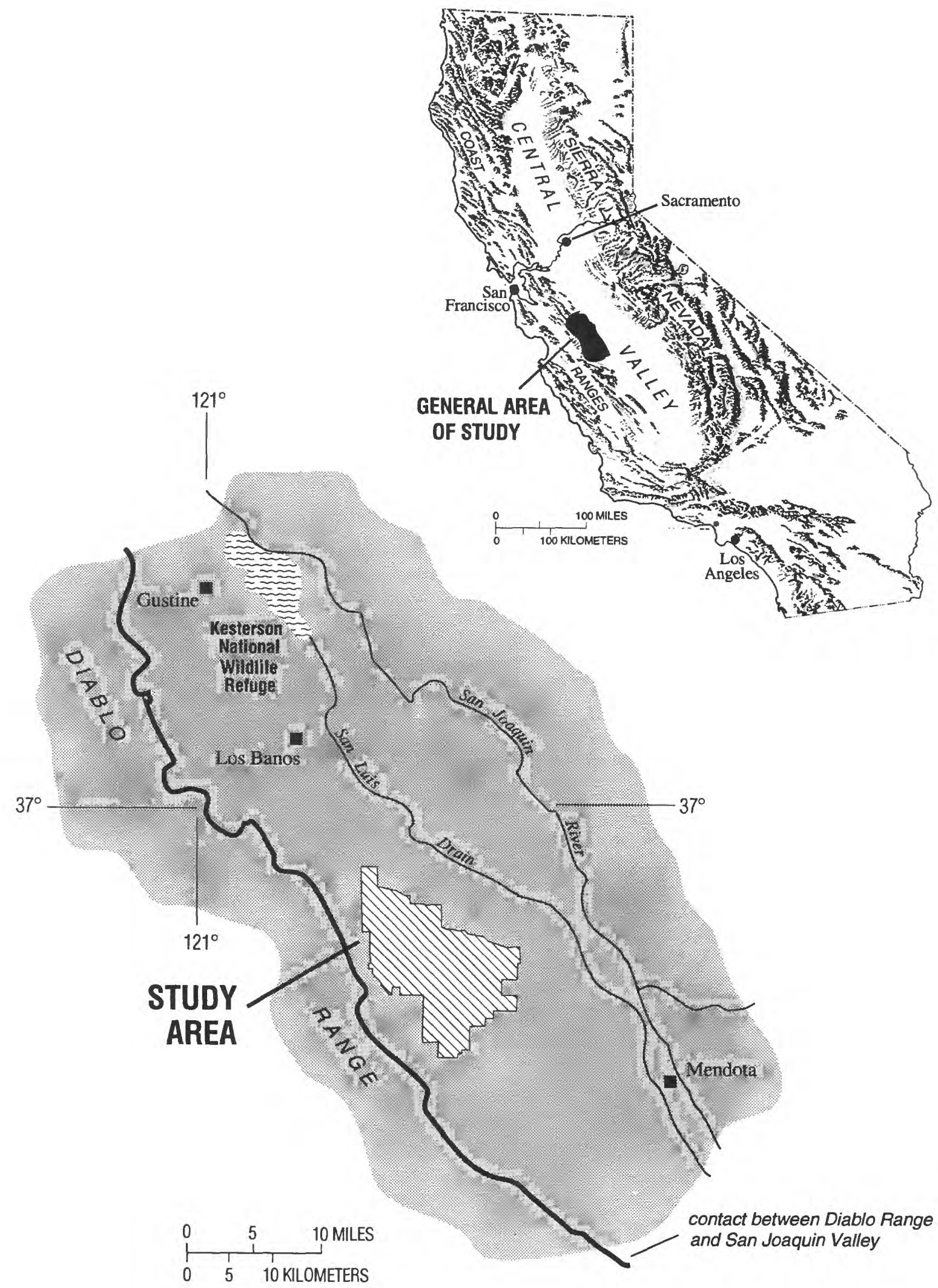

Figure 1. Part of the western San Joaquin Valley and general area of study. 
this reason, the ground-water flow model was used to calculate the water budget and simulate the distribution of ground-water flow paths to the drainage systems.

\section{BACKGROUND}

Agriculture in the western San Joaquin Valley is dependent on irrigation. Prior to 1958, ground-water pumping was the primary source of irrigation water, and historic water demands resulted in drawdowns of the potentiometric surface as much as 30 to $60 \mathrm{~m}$ below predevelopment conditions (Belitz and Heimes, 1990). After 1958, and upon completion of the California Aqueduct and Central Valley Projects, the principal source of irrigation water became surface water imported from northern California. The availability of surface water reduced the need for pumping, and recharge from percolating irrigation water has resulted in a rise in the potentiometric surface and areal expansion of a shallow water table (Belitz and Heimes, 1990). In 1988, about $460 \mathrm{~km}^{2}$ of the central part of the western San Joaquin Valley was underlain by a water table within $1.8 \mathrm{~m}$ of land surface (Belitz and others, 1992). On-farm drainage systems are used in many areas affected by the shallow water table to prevent water-logging and the accumulation of salts in the root zone.

On-farm drainage systems can affect ground-water flow in the upper part of the aquifer (Fio and Deverel, 1991; Leighton and others, 1992). Hydraulic-head and drainflow transients indicate that hydrologic conditions beneath a field are affected by irrigation activities in areas upslope of the field. Furthermore, median hydraulic heads measured in one field show that ground-water flow is upward towards the drainage system from depths as great as $15 \mathrm{~m}$ below land surface (Deverel and Fio, 1991). Therefore, quantification of contributing sources to drainflow require detailed information on geohydrologic conditions for an area considerably larger than single fields and for depth intervals substantially deeper than the water table. In particular, estimates of irrigation recharge for drained and (or) undrained areas upslope of the field, and delineation of regional ground-water flow paths intercepted by the drainage systems beneath the field, are necessary to determine sources of drainflow.

\section{STUDY AREA}

The study described in this report was done within the service area of a water district in the central part of the western San Joaquin Valley (Panoche Water District), at a scale of observation that is intermediate to previous field- and regional-scale modeling studies conducted by Fio and Deverel (1991) and Belitz and others (1992). This was done to include drained and undrained farm fields at a level of detail sufficient for quantifying the contribution of regional ground-water flow to on-farm drainflow. The boundaries of the study area, the ground-water flow model developed for this study, the flow model developed by Belitz and others (1992), and the location of the field model of Fio and Deverel (1991) are shown in figure 2. [The model of Belitz and others (1992) and the model of Fio and Deverel (1991) are herein referred to as the "regional model" and "field model," respectively]. The study area is about $3 \mathrm{~km}$ west of the field model and overlaps the northern part of the regional model. The southern boundary of the regional model actually extends about $19 \mathrm{~km}$ south and beyond the area shown in figure 2, but the excluded areas are not discussed or evaluated in this report.

The study area generally coincides with the northern part of regional-scale studies of lithology (Laudon and Belitz, 1991), a water budget for the central part of the valley (Gronberg and Belitz, 1992), the character and evolution of the ground-water flow system (Belitz and Heimes, 1990), and ground-water flow modeling (Phillips and Belitz, 1991; Belitz and others, 1992; Belitz and Phillips, 1992). Therefore, methods and results of model construction and parameter estimation in this study generally are consistent with those used in regional studies. In circumstances where additional data were available, model construction and parameter estimation were modified to reflect the new data. The net result is a model that enhances the reproduction of average ground-water flow conditions in the study area and generally reproduces conditions simulated by the regional model in areas between the study area and model boundaries.

On-farm drainage systems in the study area consist of a parallel network of perforated drain laterals buried at variable depths and spacings. The drain laterals typically are between 1.8 and $2.7 \mathrm{~m}$ below land surface and are spaced horizontally from 30 to $180 \mathrm{~m}$ apart (Panoche Water District, written commun., 1989). The distribution of drain lateral density (calculated as the length of drain lateral per unit area) is shown in figure 3 . The approximate age of the drainage systems, as indicated by installation dates, shows that most of the drainage systems in the northern part of the study area and on the Little Panoche Creek fan were installed prior to 1975 (fig. 4). The younger drainage systems (installed after 


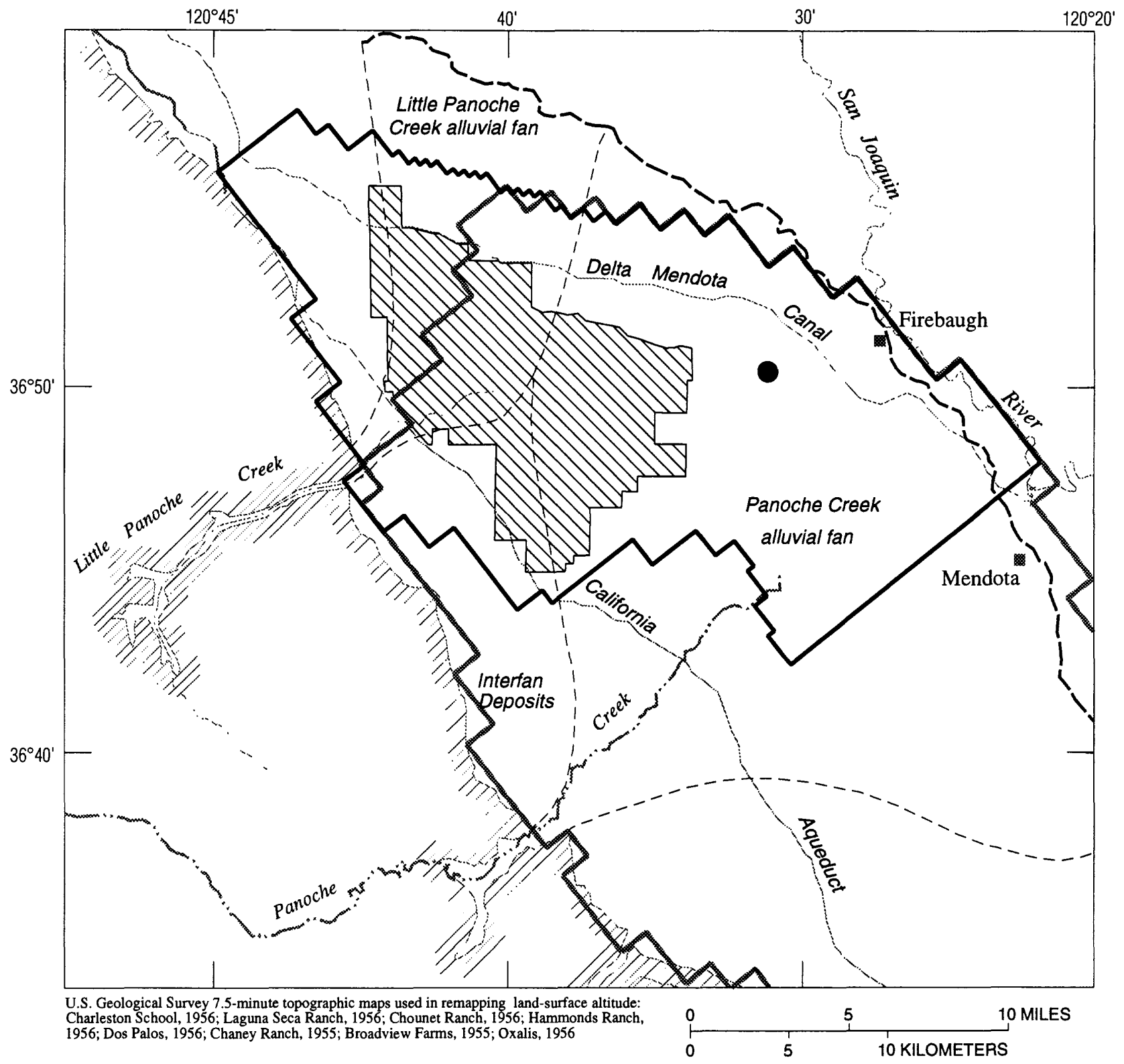

\section{EX P L A N A T I O N}

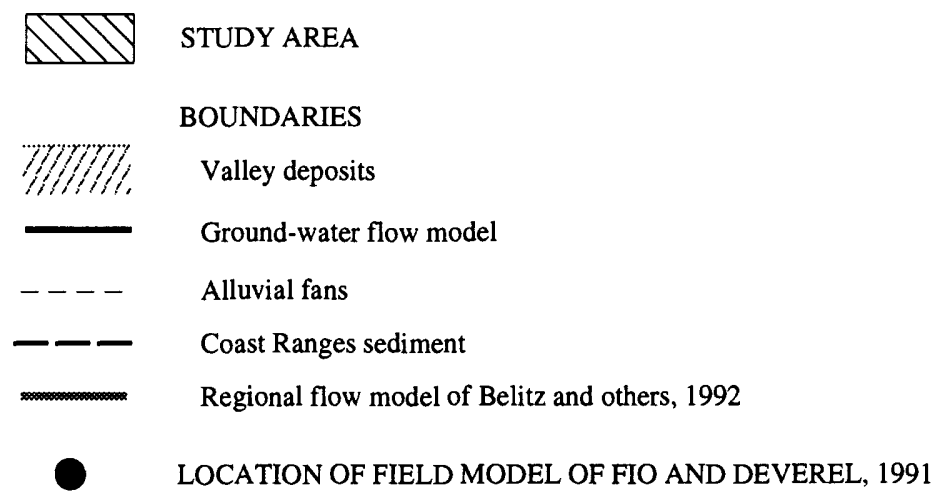

Figure 2. Study area and boundaries of the flow model, regional model, and field model. 


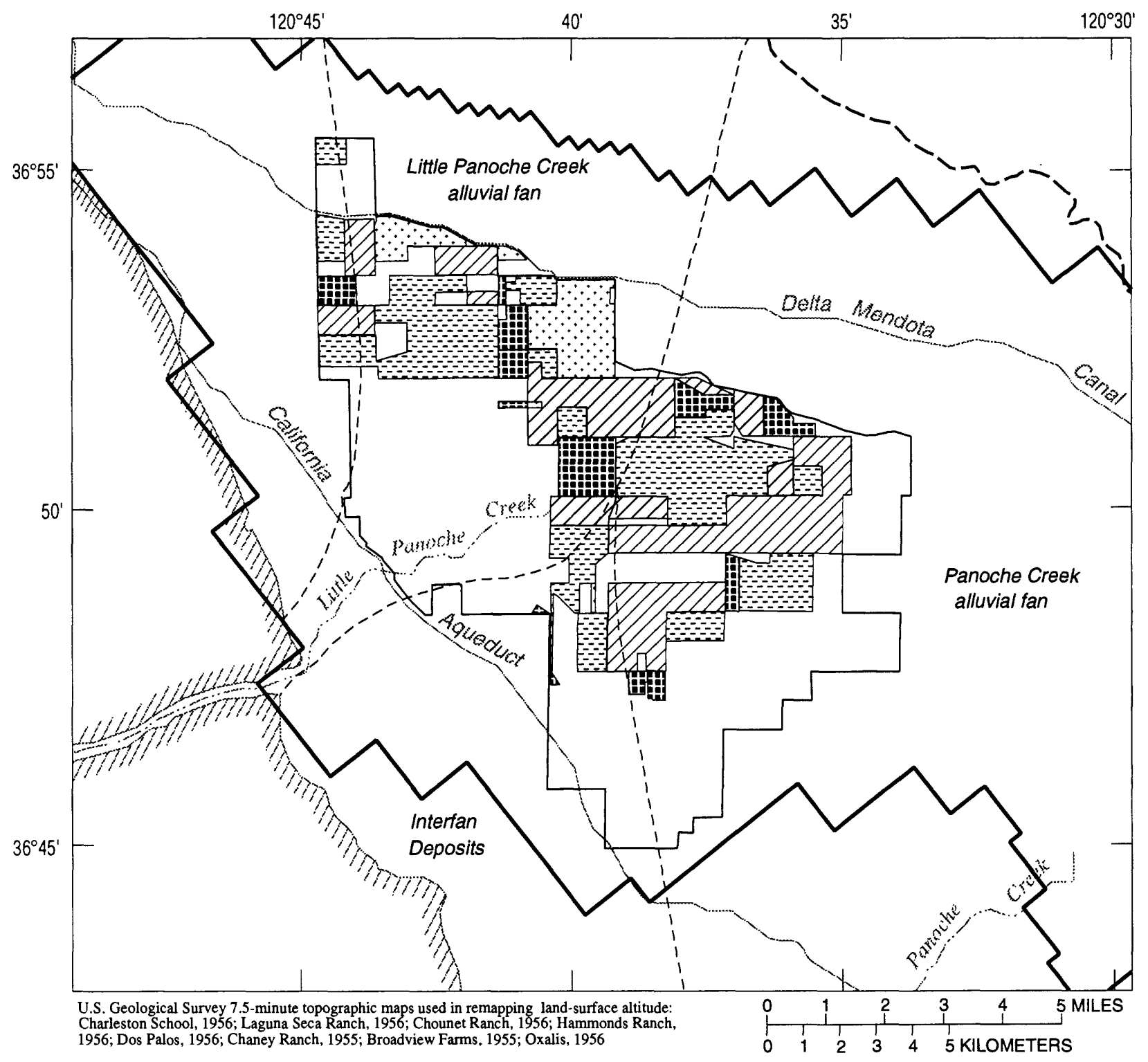

EXPLA NATIO N

DRAIN LATERAL DENSITY (meters per square kilometers)

$\because \because \because$

Less than 4,500

4,501 to 9,000

9,001 to 13,500
Greater than 13,500
BOUNDARIES

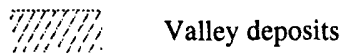

Ground-water flow model

- Study area

- Alluvial fans

- - Coast Ranges sediment

Figure 3. Distribution of drain-lateral density (blank areas in study area are undrained; drain-lateral density in areas outside the study area boundaries is not shown). 


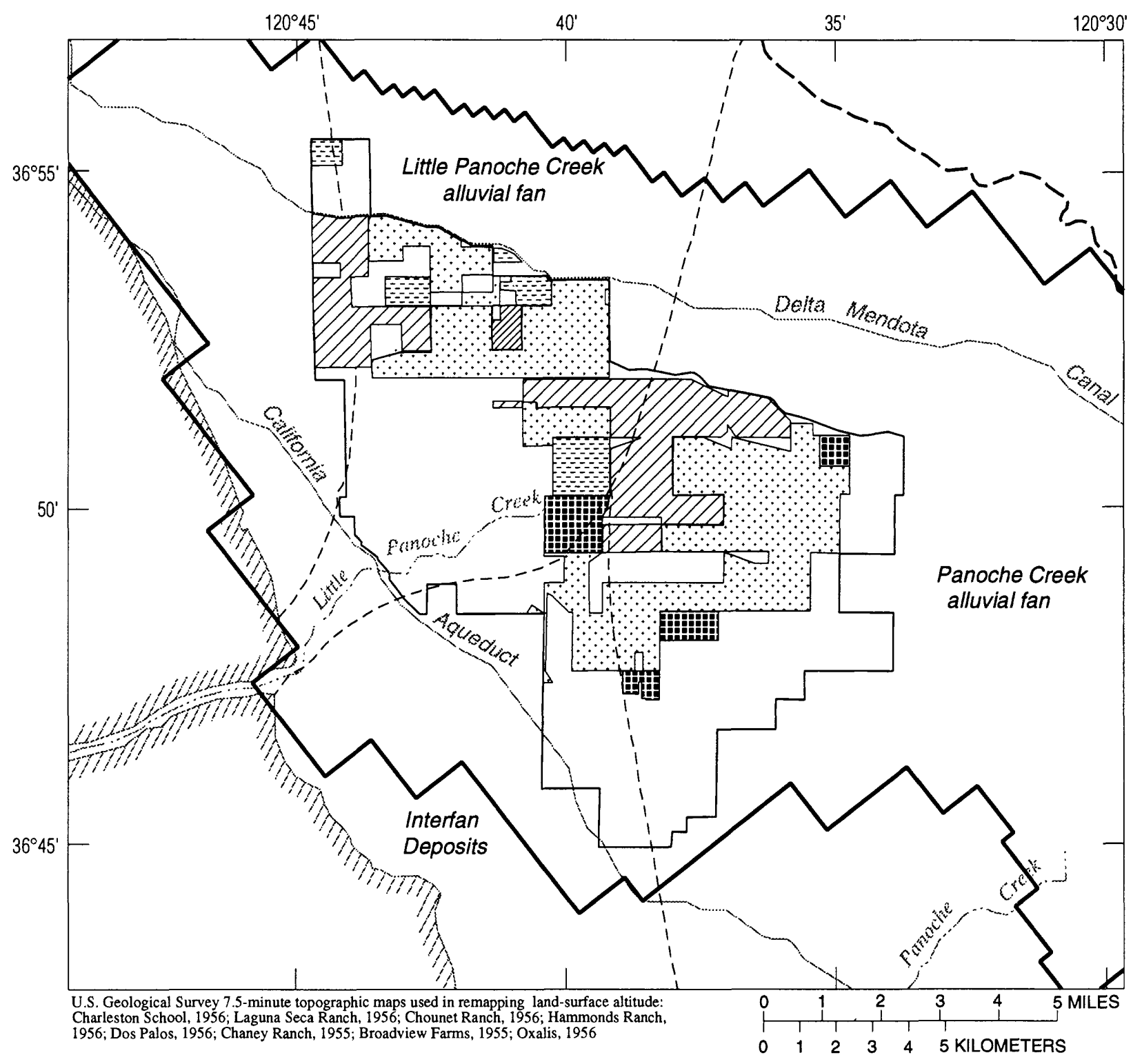

E X P L A N A T I O N

\begin{tabular}{|c|c|c|c|}
\hline & INSTALLATION DATES & & 3OUNDARIES \\
\hline$\because \because \because$ & Unknown & 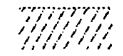 & Valley deposits \\
\hline 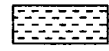 & Prior to 1966 & & Ground-water flow model \\
\hline DZTA & Between 1966 and 1975 & & Study area \\
\hline 进事 & After 1975 & $\begin{array}{l}---- \\
---\end{array}$ & $\begin{array}{l}\text { Alluvial fans } \\
\text { Coast Ranges sediment }\end{array}$ \\
\hline
\end{tabular}

Figure 4. Installation dates of selected drainage systems in part of the western San Joaquin Valley (blank areas in study area are undrained; drained areas outside the study area boundaries are not shown). 
1975) are in the southeastern part of the study area and mostly on the Panoche Creek Fan. This general decrease in drainage system age from the north to the south parallels the historical rise and areal expansion of the regional water table (Belitz and Heimes, 1990).

\section{DESCRIPTION OF THE WATER BUDGET}

A water-budget approach was used to quantify contributing sources to drainflow. The magnitude and relative significance of budget components were determined by the volume of aquifer or control volume studied. In this report, the upper and lower boundaries of the control volume coincide with the top and bottom boundaries of the flow model. The horizontal boundaries can be changed to include single fields, subareas consisting of multiple fields, or the entire study area encompassing all the fields.

For illustrative purposes, figure 5 shows a section of a part of a typical field in the study area, an underlying drain lateral, and the shallow ground-water

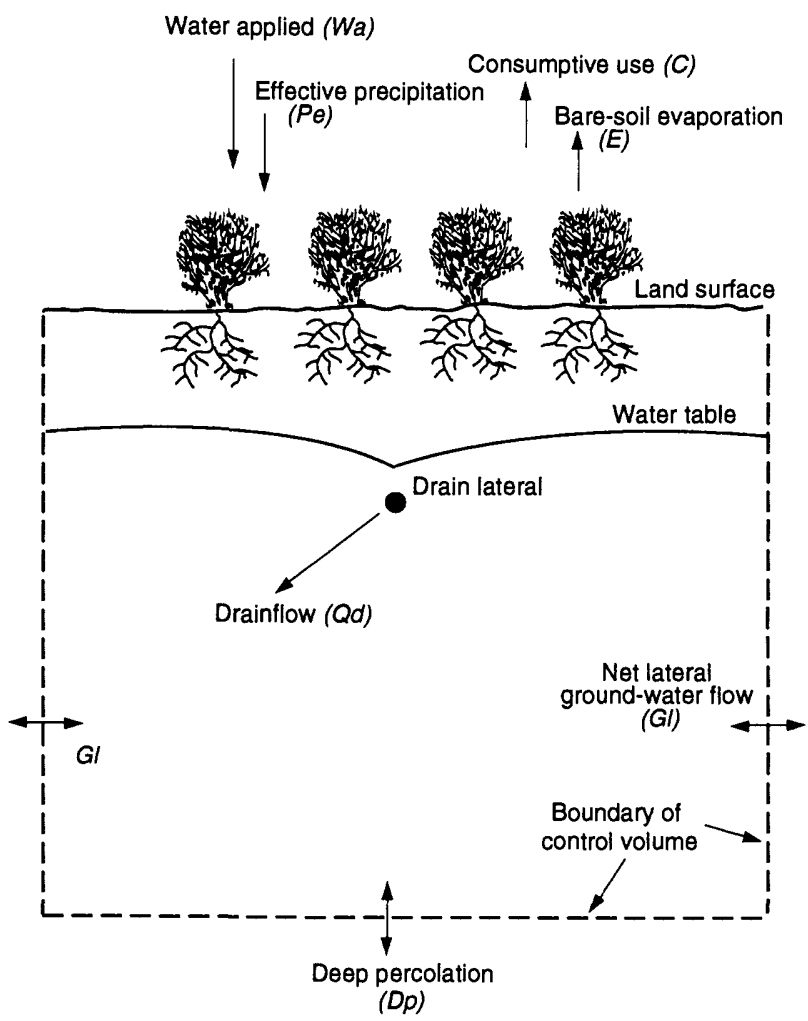

Figure 5. Control volume and water-budget components in a part of a typical field in the western San Joaquin Valley. flow system. The section is of unit depth in the plane perpendicular to the face of the section. Water additions consist of irrigation water applied (sum of surface- and ground-water deliveries), precipitation infiltrating the soil surface (effective precipitation), and ground-water flow into the section. Water subtractions consist of consumptive use (water transpired by the specific crops grown on the field, retained by the plant tissue, and evaporated from adjacent soil surfaces during the growing season), annual evaporation of shallow ground water from the soil surface (bare-soil evaporation), drainflow, and ground-water flow out of the section. The vertical component of flow across the lower boundary of the section is defined in this study as deep percolation $(D p)$ and represents an addition or subtraction of water depending on local geohydrologic conditions.

Assuming that hydrologic conditions are steady and the annual change in water storage in the saturated and unsaturated zones is negligible, the water budget for the general conditions depicted in figure 5 are:

$$
W a+P e-C-E-Q d \pm G l \pm D p=0,
$$

where

$W a$ is water applied from surface- and groundwater sources, in cubic meters per year;

$P e$ is effective precipitation, in cubic meters per year;

$C$ is consumptive use by crops, in cubic meters per year;

$E$ is bare-soil evaporation, in cubic meters per year;

$Q d$ is drainflow, in cubic meters per year;

$G l$ is net sum of lateral ground-water flow components in and out of the control volume, in cubic meters per year;

$D p$ is net sum of deep percolation components in and out of the control volume, in cubic meters per year.

The hydrologic terms in equation 1 consist of recharge, drainflow, and ground-water flow components. Water applied (Wa), effective precipitation $(P e)$, and consumptive use $(C)$ were estimated in this study on an annual basis using a combination of field data and crop calendars. In contrast, bare-soil evaporation $(E)$, drainflow $(Q d)$, and ground-water flow ( $G l$ and $D p)$ is estimated using the flow model. Comparison between model results and measured hydraulic heads, estimated bare-soil evaporation, and measured drainflow provide insight into model reliability and the simulated water budget. 
Equation 1 can be simplified by focusing on the budget components in the saturated ground-water flow system. Recharge to the saturated zone $(R)$ is calculated as the sum of water applied and effective precipitation, less consumptive use:

$$
R=W a+P e-C,
$$

where

$R$ is recharge to the saturated zone, in cubic meters per year.

Substitution of equation 2 into equation 1 and solving for drainflow identifies the water-budget components in the saturated zone affecting drainflow:

$$
Q d=R-E \pm G l \pm D p .
$$

The two ground-water components ( $G l$ and $D p$ ) represent the potential contribution of regional ground water to drainflow.

\section{APPROACH}

A ground-water flow model was used to calculate the water budget described by equation 3 . The flow model was developed using geohydrologic data collected during 1987-91, and simulates average hydrologic conditions represented by the data set. The resulting water budget was then used to quantify the recharge and ground-water components contributing to annual drainflow. In circumstances when drainage systems intercept lateral ground-water flow and upward-moving deep percolation, the model results were useful for delineating the upslope areas that contribute to the downslope drainflow.

The flow model was constructed from a gridded interpretation of water-level and textural data that were physically represented by arrays of numerical information. These data arrays are not included in this report, but general reproduction is possible using the tables, maps, and figures presented. The maps and figures show considerable detail in the study area, but exclude some of the marginal areas near the model boundaries. All data collected during this study are presented in this report, and readers interested in the excluded areas are referred to the regional investigations previously cited.

In some circumstances, maps of contoured data were constructed using the Surface III mapping package developed by Sampson (1988). Otherwise, the maps were hand contoured using the professional judgment of the author. The Surface III package uses a moving average to estimate values of a surface at the nodal points of a rectangular grid. The grid used in this study was oriented with the principal axis of the flow model and has a nodal spacing of $402 \mathrm{~m}$ in the $x$ and $y$ directions. Values at each node were estimated by calculating a constrained distancesquared weighted average of the eight nearest data points, and the maps were contoured from the gridded values and plotted. In areas of sparse data, the maps should be regarded as only showing general trends; whereas, in areas where data are variable and closely spaced, the Surface III package may produce smoothed estimates of the data.

\section{WATER-LEVEL MEASUREMENT}

Water-level measurements were made biweekly from February 1990 through January 1991 in shallow and deep observation wells in the study area. Water levels from the shallow wells define the surface of the water table, whereas water levels in the deeper wells provide information on the hydraulic-head surface at greater depth. Figure 6 shows the locations of the shallow wells (fully perforated from land surface to depths ranging from 3 to $9 \mathrm{~m}$ below land surface) and the locations of sites 1 through 7 where clusters of one to four observation wells are located $(0.6 \mathrm{~m}$ perforated intervals centered at depths ranging from 3.8 to $29.3 \mathrm{~m}$ below land surface). The seven cluster sites are approximately aligned with three geohydrologic sections $\left(A-A^{\prime}, B-B^{\prime}, C-C^{\prime}\right)$ shown in figure 6.

The altitude of the water table and potentiometric head surface at greater depth was estimated from the difference between land-surface altitude (fig. 7) and measured depth to water. [As a consequence of land subsidence due to compaction of the aquifer matrix, the altitude of land surface was remapped using U.S. Geological Survey 7.5-minute topographic maps and land subsidence maps as described in detail by Belitz and others (1992)]. Maps of the water table and deeper hydraulic-head surfaces were estimated by the difference between land-surface altitude and contoured depths to water. This was done to maintain internal consistency between land-surface topography, altitude of the water table, and deeper hydraulic heads. Because most of the study area is characterized by gentle topography and relatively small horizontal hydraulic-head gradients, this approach is reasonable for locations in the study area. In areas of steep topography or where data are sparse, this approach may result in significant errors, and results outside of the study area boundaries are interpreted with caution. 


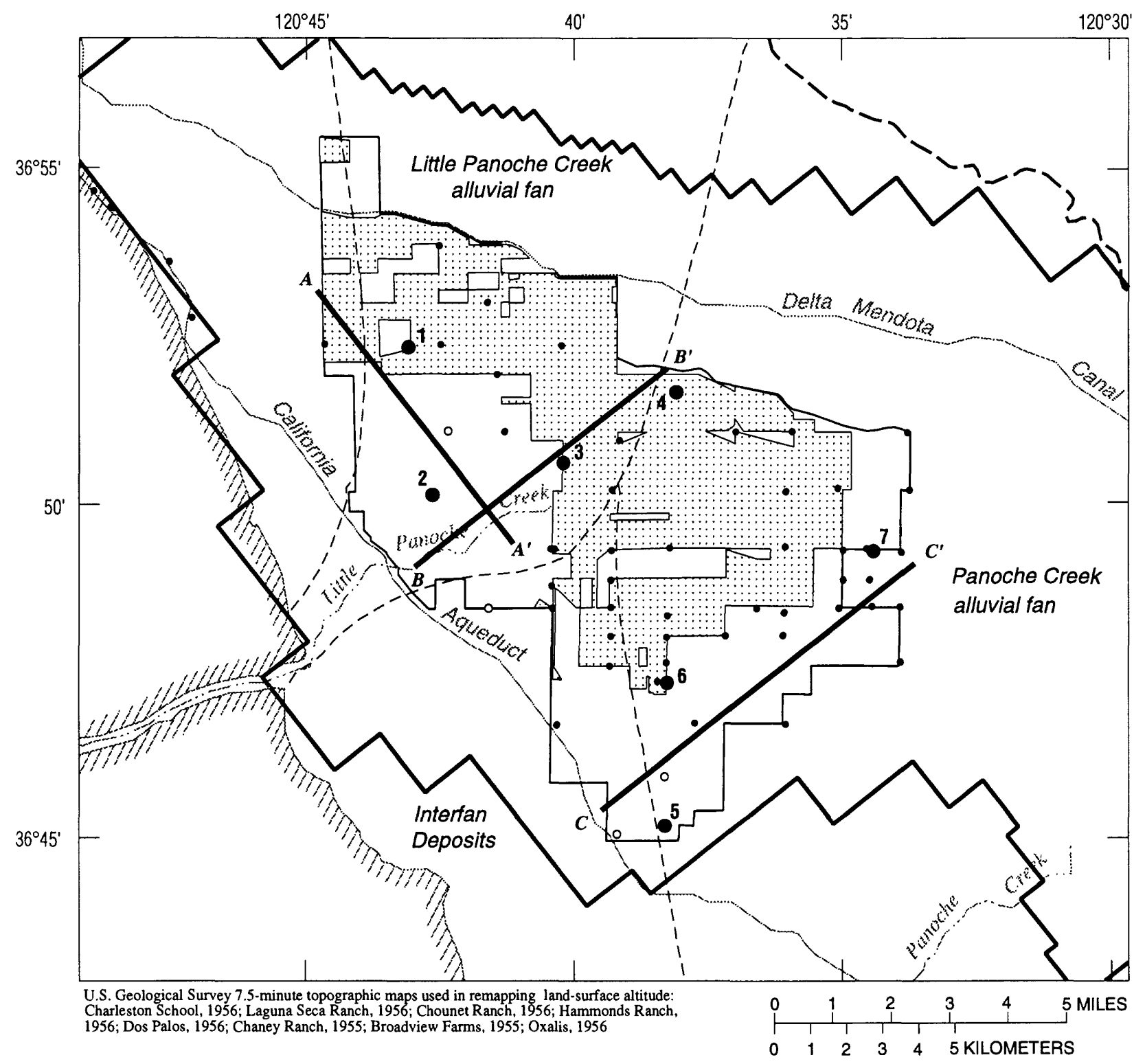

\section{EX P L A N A T I O N}

\begin{tabular}{|c|c|}
\hline \multirow[t]{2}{*}{ 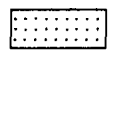 } & AREA UNDERLAIN BY DRAINAGE SYST \\
\hline & BOUNDARIES \\
\hline 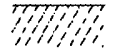 & Valley deposits \\
\hline & Ground-water flow model \\
\hline & Study area \\
\hline---- & Alluvial fans \\
\hline--- & Coast Ranges sediment \\
\hline$C^{\prime}$ & $\begin{array}{l}\text { LINE OF GEOHYDROLOGIC SECTION - } \\
\text { Shown in figures } 8 \text { and } 12\end{array}$ \\
\hline
\end{tabular}

- DRY OBSERVATION WELLS

- $\quad$ SHALlOW WELl USED TO MEASURE DEPTH TO WATER TABLE

5 CLUSTER SITE AND NUMBER - Site at which one or more observation wells are installed at different depths

Figure 6. Areal distribution of shallow observation wells, cluster sites, and geohydrologic sections in part of the western San Joaquin Valley (blank areas in study area are undrained; drained areas outside the study area boundaries are not shown). 


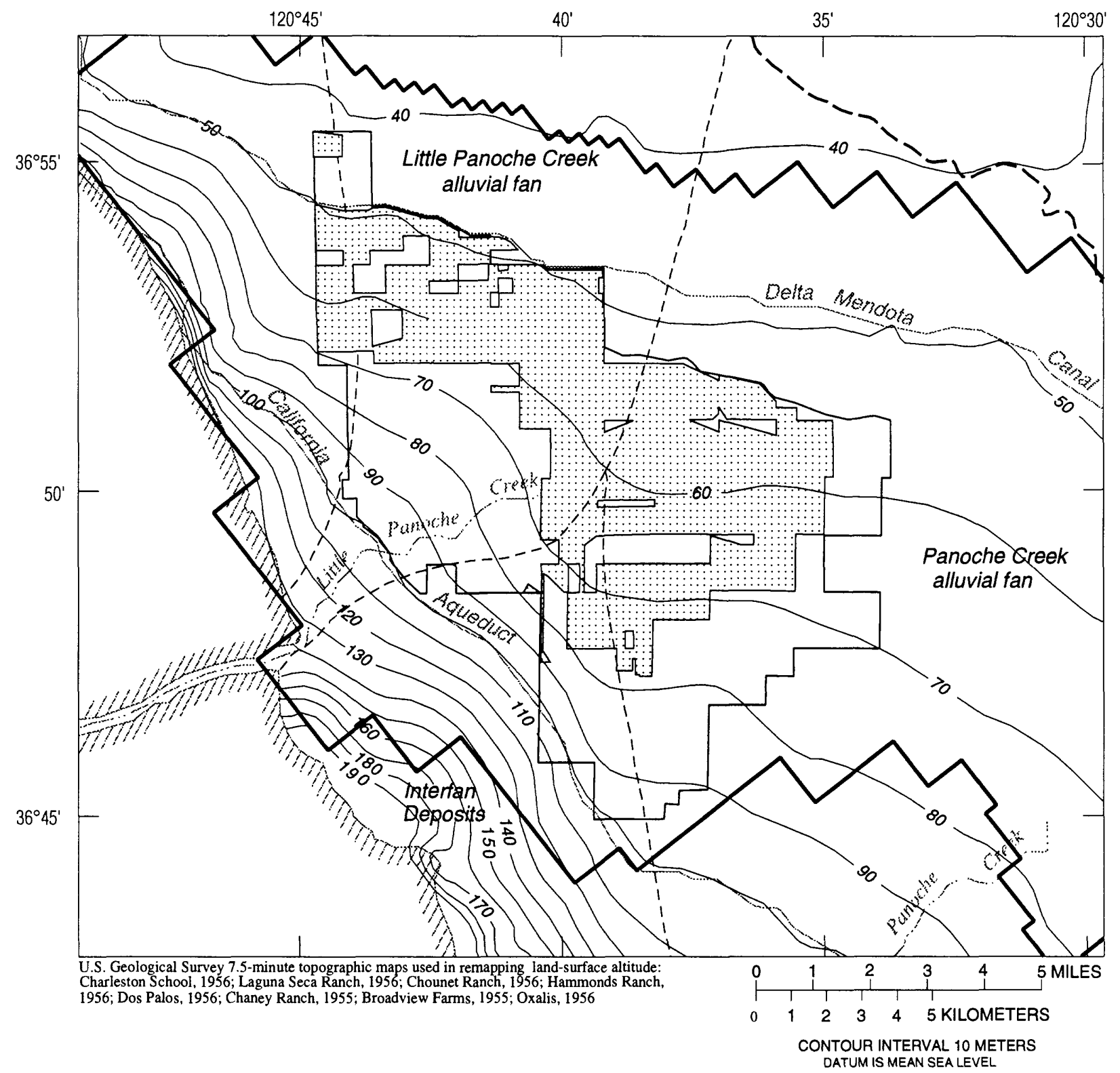

\section{EXPLA NATIO N}

: AREA UNDERLAIN BY DRAINAGE SYSTEMS

\section{BOUNDARIES}

磷源， Valley deposits

$\begin{array}{ll}\text { Ground-water flow model } \\ & \text { Study area }\end{array}$

- $\quad$ Alluvial fans

- Coast Ranges sediment

Figure 7. Topography in modeled area (blank areas in study area are undrained; drained areas outside the study area boundaries are not shown). 


\section{SIMULATING GROUND-WATER FLOW}

A steady-state, three-dimensional, numerical ground-water flow model is used to reproduce the distribution of hydraulic heads and volumetric fluxes in the study area (McDonald and Harbaugh, 1988). Steady-state, three-dimensional movement of ground water of constant density through porous earth material is described by the following partialdifferential equation:

$$
\begin{aligned}
\partial / \partial x\left(K_{x x} \partial h / \partial x\right)+\partial / \partial y\left(K_{y y} \partial h / \partial y\right) & \\
& +\partial / \partial z\left(K_{z z} \partial h / \partial z\right)-W=0,
\end{aligned}
$$

where

$K_{x x}, K_{y y}, K_{z z}$ are values of the hydraulic conductivity along the $x, y$, and $z$ coordinate axis, which are assumed to be parallel to the major axes of hydraulic conductivity, in meters per year;

$h$ is the hydraulic head, in meters; and

$W$ is a volumetric flux per unit volume and represents sources and (or) sinks of water, in year ${ }^{-1}$.

Specifications of flow and (or) head conditions at the boundaries of the model constitute a mathematical representation of the ground-water flow system, and when solved, provide the hydraulic-head distribution for the $x-y-z$ space.

An approximate solution to equation 4 is obtained using the finite-difference method whereby the continuous system described by equation 4 is replaced by a finite set of discrete points in space. The model area is discretized into a grid of finite-difference model cells, and solving the set of resulting finite-difference equations gives the head values for each cell (McDonald and Harbaugh, 1988).

\section{SOURCES AND SINKS}

Sources and sinks in the ground-water flow model include specified fluxes, such as recharge to the saturated zone, and head-dependent fluxes, such as bare-soil evaporation and drainflow (McDonald and Harbaugh, 1988). Recharge to the saturated zone is calculated from information on water applied, consumptive use by crops, and effective precipitation, and is specified in the model. Bare-soil evaporation and drainflow are simulated by the model using linear functions (McDonald and Harbaugh, 1988). Parameters for the linear functions were determined by theoretical considerations and derived empirically from physical data, respectively.

\section{CALCULATING EQUIVALENT HYDRAULIC CONDUCTIVITY}

The spatial distribution of aquifer permeability simulated by the flow model is approximated by the distribution of horizontal and vertical model cell conductance. Model cell conductance is calculated from equivalent hydraulic conductivity (McDonald and Harbaugh, 1988), and equivalent hydraulic conductivity is calculated using the approach developed for the regional model reported by Phillips and Belitz (1991).

Phillips and Belitz (1991) concluded that equivalent horizontal hydraulic conductivity in the regional model is best calculated as a weighted arithmetic average of the hydraulic conductivities of coarse- and fine-grained lithologic endmembers:

$$
K H=\left(K_{C} * F_{C}\right)+\left(K_{f} * F_{f}\right),
$$

where

$K H$ is equivalent horizontal hydraulic conductivity, in meters per year;

$K_{C}$ is hydraulic conductivity of the coarsegrained lithologic endmember, in meters per year;

$F_{C}$ is fraction of coarse-grained endmember, spatially variable;

$K_{f}$ is hydraulic conductivity of the finegrained lithologic endmember, in meters per year;

$F_{f}$ is fraction of fine-grained endmember, spatially variable; and

$$
F_{C}+F_{f} \text { is } 1 \text {. }
$$

Coarse-grained sediment is defined by Phillips and Belitz (1991) as consisting principally of sand, clayey and silty sand, gravel, and clayey, silty, and sandy gravel; fine-grained sediment consists principally of clay, silt, and sandy clay and silt. In the vertical direction, Phillips and Belitz (1991) concluded that equivalent vertical hydraulic conductivity can be calculated as either a weighted geometric average or weighted harmonic average of the hydraulic conductivities of coarse- and fine-grained lithologic endmembers: 


$$
K V_{g}=\left(K_{C}^{F_{c}} * K_{f}^{F_{f}}\right) \text {, }
$$

or,

$$
K V_{h}=\frac{1}{\left(F_{c} / K_{C}\right)+\left(F_{f} / K_{f}\right)},
$$

where

$K V_{g}$ is equivalent vertical hydraulic conductivity calculated using a weighted geometric average, in meters per year; and

$K V_{h}$ is equivalent vertical hydraulic conductivity calculated using a weighted harmonic average, in meters per year.

Final calibration of the regional model concluded that equivalent vertical conductance is best calculated using the weighted harmonic average (Belitz and others, 1992).

Endmember hydraulic conductivities for calculating model cell conductances were determined by Belitz and Phillips (1992) from measured and simulation results. The hydraulic conductivity used for the coarse-grained endmember $(3,500 \mathrm{~m} / \mathrm{y})$ was the mean value of 17 slug tests conducted on wells having perforated intervals located exclusively in coarsegrained deposits (Belitz and others, 1992). The fine-grained endmember (alluvial clay) was estimated as $0.44 \mathrm{~m} / \mathrm{y}$ during calibration of the regional model (Belitz and others, 1992).

The model developed for this study is tested using either the geometric or harmonic averages to calculate equivalent hydraulic conductivity in the vertical direction. Model results are assessed using statistical analyses on model heads from cells representing the general location and depth interval of observation wells and comparisons between measured and simulated drainflow. The statistical values used to assess model heads were the root mean square error (RMSE) and bias (BIAS):

$$
\begin{gathered}
\mathrm{BIAS}=\sum_{i=1}^{N}\left[h_{o b s(i)}-h_{s i m(i)}\right], \\
\mathrm{RMSE}=\sqrt{\sum_{i=1}^{n} \frac{\left[h_{o b s(i)}-h_{s i m(i)}\right]^{2}}{n}},
\end{gathered}
$$

where

$n$ is number of measured values;

$h_{o b s(i)}$ is head at an observation point, in meters; and $h_{\text {sim(i) }}$ is head in the model cell representing the corresponding observation point, in meters.

Phillips and Belitz (1991) also used the RMSE and BIAS during preliminary calibration of the regional model. A small RMSE indicates good average agreement between measured and simulated heads. If the BIAS is positive in sign, simulated heads generally are smaller than measured. Conversely, a negative BIAS indicates simulated heads generally are larger than measured.

\section{ESTIMATING GROUND-WATER FLOW PATHS AND ADVECTIVE TRAVELTIMES}

Ground-water flow paths and advective traveltimes are estimated from the specific discharge calculated by the model for each finite-difference cell. First, specific discharge is divided by porosity to calculate average linear velocity for each cellular component of flow in the $x, y$, and $z$ directions. A velocity vector field is then generated from the three velocity components using simple linear interpolation of the components between adjacent faces of the finite-difference cells. For steady-state simulations, an analytical expression of the flow path in each cell is calculated by direct integration of the velocity components (Pollock, 1988). This method calculates the shape and direction of ground-water flow paths and estimates advective traveltimes by integration of the linear velocity components along the flow path (Pollock, 1989).

Estimates of advective traveltimes are sensitive to the specified values of porosity because linear velocity is inversely proportional to porosity. Mean total porosity of coarse- and fine-grained sediments in the western San Joaquin Valley is about 0.41 and 0.42 , respectively (Belitz and others, 1992). Only a fraction of the total porosity is interconnected and contributes to the advective movement of water and solutes, hence the drainable porosity or instantaneous specific yield was used to calculate linear velocities. The specific yield of sediments in the western San Joaquin Valley may range from 0.2 to 0.3 (Belitz and others, 1992), and a value of 0.2 was assumed reasonable for the drainable porosity of predominantly coarse-grained sediments. The drainable porosity of fine-grained sediments was assumed to be 0.1 based on neutron-probe measurements following an irrigation event in one field consisting of clay loam (Fio and Deverel, 1991). 


\section{DELINEATING CONTRIBUTING SOURCES TO DRAINFLOW}

The ground-water flow model simulates a net flux averaged over the volume of the model cell. The area of the model cells was such that several cells are required to represent a single field and drainage system in the study area, and the thickness of the cells simulating drainflow $(3 \mathrm{~m})$ were such that most of the ground water flowing into the cell is discharged as drainflow (as shown later during the discussion of the water budget, drainflow is about five times greater than bare-soil evaporation in the drained area and thus drainage systems are major sinks in the model). Contributing sources to drainflows can therefore be estimated from the net flux of ground water moving into a model cell simulating drainflow. One must exercise caution when using this approach because quantitative analysis of model results at the scale of individual model cells generally is unwarranted (Pollock, 1989), but in this study, the results from model cells are assessed in a combined fashion to estimate contributing sources of drainflow to numerous model cells representing groups of drainage systems.

Contributing sources to drainflow were estimated by placing conceptual "particles" at a central location in each model cell that simulates drainflow; the particles were placed along the bottom face of the top model layer, below the water table and drainage systems. The particles were then tracked in a backward direction to determine the average groundwater flow path contributing to the net flux of water into the cell, and the final locations were grouped into three categories relative to potential drainflow sources. Particles that stop in the same cell as the starting location delineate areas that discharge mostly local recharge; recharge to the saturated zone is assumed to move vertically downwards through the unsaturated zone from its point of entry at land surface to the underlying water table. The maximum horizontal distance traveled by flow paths to discharge points in these cells is the width of a model cell (402 $\mathrm{m})$. Similarly, particles stopping in model cells upslope from their starting locations delineate areas that contribute significant quantities of recharge to downslope discharge. The horizontal distance traveled by these flow paths can be substantially greater than the width of a model cell. Finally, particles that stop at the lower boundary of the model identify areas that discharge upward-moving deep percolation. Simulated fluxes in the three delineated subareas were compiled and summed using the computer code ZONEBUDGET (Harbaugh, 1990).

\section{CALCULATION OF WATER BUDGET}

A steady-state modeling approach is used to reproduce average hydrologic conditions in the study area and calculate the water budget. This approach is reasonable for drained areas because water-level measurements from a regional network of shallow wells indicate that drainage systems have maintained the altitude of the water table at a fairly uniform level for 10 to 20 years (Belitz and Heimes, 1990). In areas where hydraulic heads change with time, ground-water flow is nonsteady and the model is intended only to reproduce average conditions represented by the data set. The steady-state approach is limited by its inability to simulate future hydrologic changes, and implications of simulation results for historical and (or) future trends in hydrologic conditions are limited to qualitative interpretations.

The actual construction of the ground-water flow model requires specification of physical data in a way that conforms to the geohydrologic framework of the simulated system. The geohydrologic framework is derived from physical data and represents a conceptual understanding of the relation between system inputs (for example, recharge to the saturated zone) and the resulting system outputs (for example, hydraulic head and drainflow at select locations in the model area). Development of the ground-water flow model first entails a thorough analysis of the available physical data to delineate the geohydrologic framework, followed by the specification of model geometry, boundary conditions, sources and sinks, and aquifer characteristics for simulation purposes.

\section{GEOHYDROLOGIC FRAMEWORK}

\section{REGIONAL GEOHYDROLOGY AND IRRIGATION PRACTICES}

The San Joaquin Valley is a large asymmetric trough that has been filled with as much as 9.7 vertical $\mathrm{km}$ of unconsolidated sediments (Page, 1986). In the western part of the valley, these sediments were deposited by ephemeral and intermittent streams draining the foothills and Coast Ranges that border the valley. As the streams emerge from the foothills, the velocity of flow is reduced resulting in a decreased capacity to carry sediment. The ensuing deposits or alluvial fans are typically dominated by gravel and sand at the upper slopes and along stream channels, whereas at the fan margins and in areas of relatively gentle topographic relief, the alluvium is dominated by silt and clay (Laudon and Belitz, 1991). The soils that have developed upon these fans are 
used extensively for the production of vegetables, grains, forage, and other agricultural products.

The regional ground-water flow system in the San Joaquin Valley is separated into an upper semiconfined and lower confined zone by the Corcoran Clay Member of the Tulare Formation of Pleistocene age (Page, 1986). The Corcoran Clay Member is an areally extensive lacustrine deposit of low permeability (Johnson and others, 1968), and depth to the base of the Corcoran Clay Member ranges from 120 $\mathrm{m}$ to more than $240 \mathrm{~m}$ below land surface (Bull and Miller, 1975). The saturated thickness of the semiconfined zone above the Corcoran Clay Member is as great as $150 \mathrm{~m}$ in the central part of the western valley, and ground-water flow is characterized by a regional downward component of vertical flow (Belitz and Heimes, 1990). The vertical flow is a dynamic response to historical drawdowns, percolating irrigation water, and pumping of deep ground water (Belitz and Heimes, 1990).

The climate in the valley is semiarid with annual precipitation ranging from 0.15 to $0.20 \mathrm{~m}$ (Rantz, 1969). Hydrologic conditions are dominated by agricultural activities, which contribute recharge to the ground-water flow system by percolating irrigation water. Because application rates and scheduling are related to the growing season, recharge varies in quantity and intensity during the year. The first irrigation typically consists of a preplant irrigation applied in the late winter or early spring, followed by periodic applications during the summer growing season. Recharge rates are greatest during the preplant irrigation because greater quantities of water are applied to thoroughly wet the seed bed, and the absence of crop roots increases the quantity of water reaching the saturated zone. In contrast, recharge is negligible during the harvest and winter months when fields are nonirrigated and idle.

\section{DISTRIBUTION OF SEDIMENT TEXTURE}

The distribution of texture in the upper $30 \mathrm{~m}$ of the model area is characterized by the percentage of coarse-grained sediment interpreted from well logs using the methodology described by Laudon and Belitz (1991). The study area consists of a layered sequence of sediments (fig. 8), consisting generally of about $12 \mathrm{~m}$ of predominantly fine-grained sediment in the 0 - to $12-\mathrm{m}$ interval (average fraction of coarsegrained sediment less than 50 percent) overlaying about $9 \mathrm{~m}$ of predominantly coarse-grained sediment in the 12- to $21-\mathrm{m}$ interval (average fraction of coarse-grained sediment greater than 50 percent). The predominantly coarse-grained sediment is in turn underlain by about $9 \mathrm{~m}$ of predominantly fine-grained sediment in the 21 - to $30-\mathrm{m}$ depth interval. The layering of coarse-grained sediments appears continuous in the $A-A^{\prime}$ and $B-B^{\prime}$ geohydrologic sections, but is discontinuous between sites 6 and 7 in the $C-C^{\prime}$ geohydrologic section.

Laudon and Belitz (1991) report that the fraction of coarse-grained sediment in the western San Joaquin Valley generally increases with depth from 0 to $15 \mathrm{~m}$ below land surface. They found that coarse-grained sediments are typically associated with the remnants of old mudflow and (or) stream channel deposits. The fraction of coarse-grained sediment in the $A-A^{\prime}$ geohydrologic section decreases between sites 1 and 2 , indicating a fining of texture toward the northern margin of the fan and away from the old stream channel of Little Panoche Creek. Texture in the $B-B^{\prime}$ geohydrologic section decreases in an easterly direction, probably as a result of the diminishing flow and depositional energy of Little Panoche Creek as it meanders toward the valley floor. Fine-grained sediment generally is more prevalent in the $C-C^{\prime}$ geohydrologic section than the $A-A^{\prime}$ and $B-B^{\prime}$ sections. The $C-C^{\prime}$ section is at the margin of the Panoche Creek fan, where the quantity of flow and depositional energy was smaller than in areas adjacent to the stream channel.

Areal maps of texture showing the average fraction of coarse-grained sediment in the $0-$ to $12-\mathrm{m}$, 12- to $21-\mathrm{m}$, and $21-$ to $30-\mathrm{m}$ depth intervals are plotted in figures 9,10 , and 11. (As discussed later, these plots show the general distribution of sediment texture in model layers 1 through 4,5 through 7 , and 8 , respectively.) The predominantly coarse-grained sediments in the 12- to $21-\mathrm{m}$ depth interval appear continuous beneath a substantial part of the study area. These texture maps show average trends, but do not reflect the substantial heterogeneity in the bore-hole data within the two relatively broad classifications identifying coarse- and fine-grained sediment. For example, coarse-grained sediment near the head of the Little Panoche Creek fan consists of about $12 \mathrm{~m}$ of unsorted sand and gravel (6- to $18-\mathrm{m}$ depth interval at site 2), but grades into mostly fine- and medium-grained sand at the distal fan locations (sites 3 and 4). Some gravel was found at site $3(0.5-\mathrm{m}$ thick deposit in the 9.3- to $9.8-\mathrm{m}$ depth interval), but the gravel deposits were considerably less than those at site 2. Similarly, the thickness and lateral extent of dense clay bodies penetrated by the boreholes generally increase in an easterly direction and toward the 


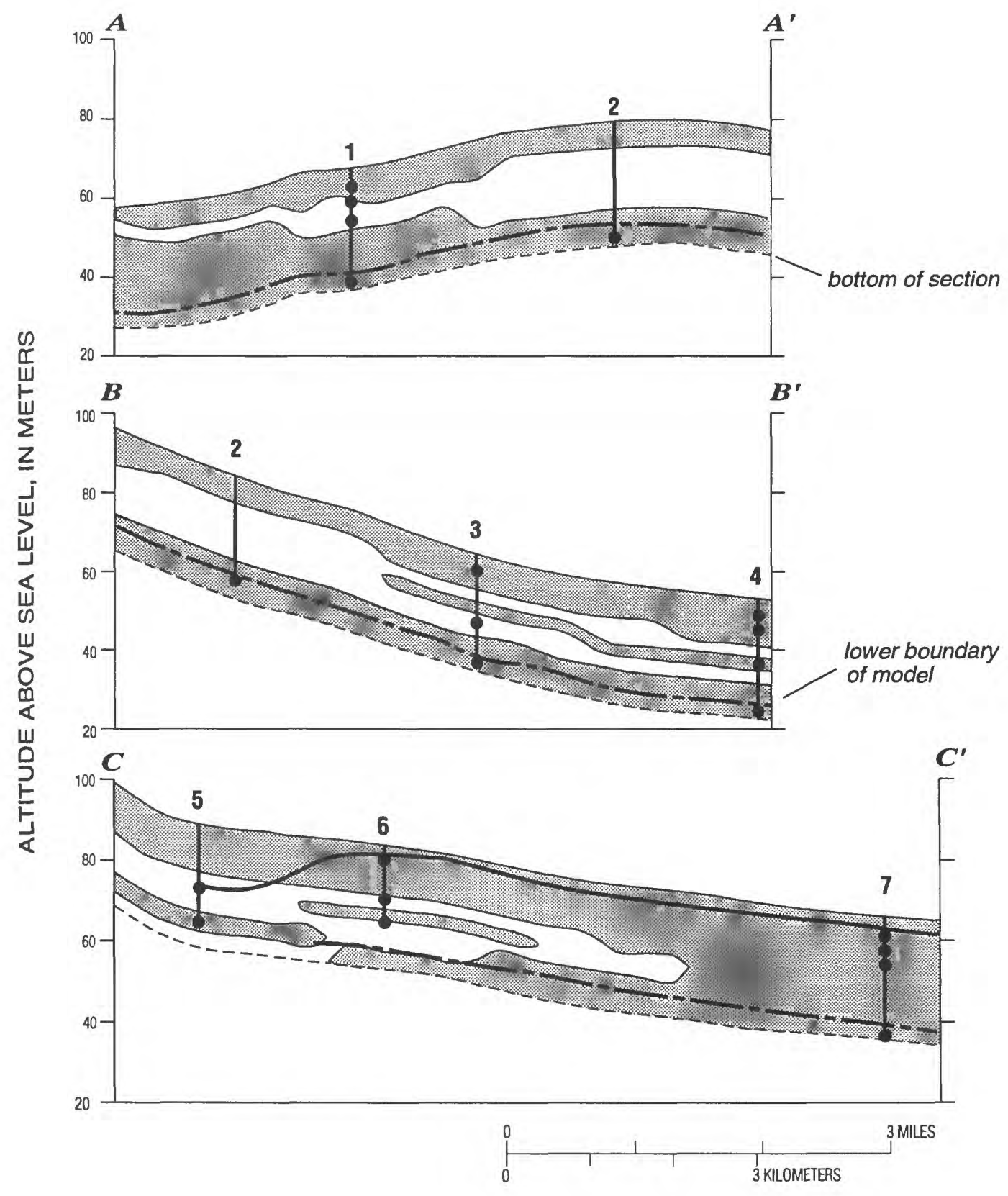

EXPLANATION

PREDOMINANTLY FINE-GRAINED SEDIMENT

PREDOMINANTLY COARSE-GRAINED SEDIMENT

6 - CLUSTER SITE AND NUMBER - Site at which one or more

observation wells are installed at different depths

CENTER OF PERFORATED INTERVAL OF INDIVIDUAL

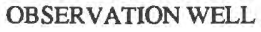

Figure 8. Textural distribution of the upper 30 meters of sediment in geohydrologic sections $A-A^{\prime}, B-B^{\prime}$, and $C-C^{\prime}$. Locations of sections shown in figure 6. 


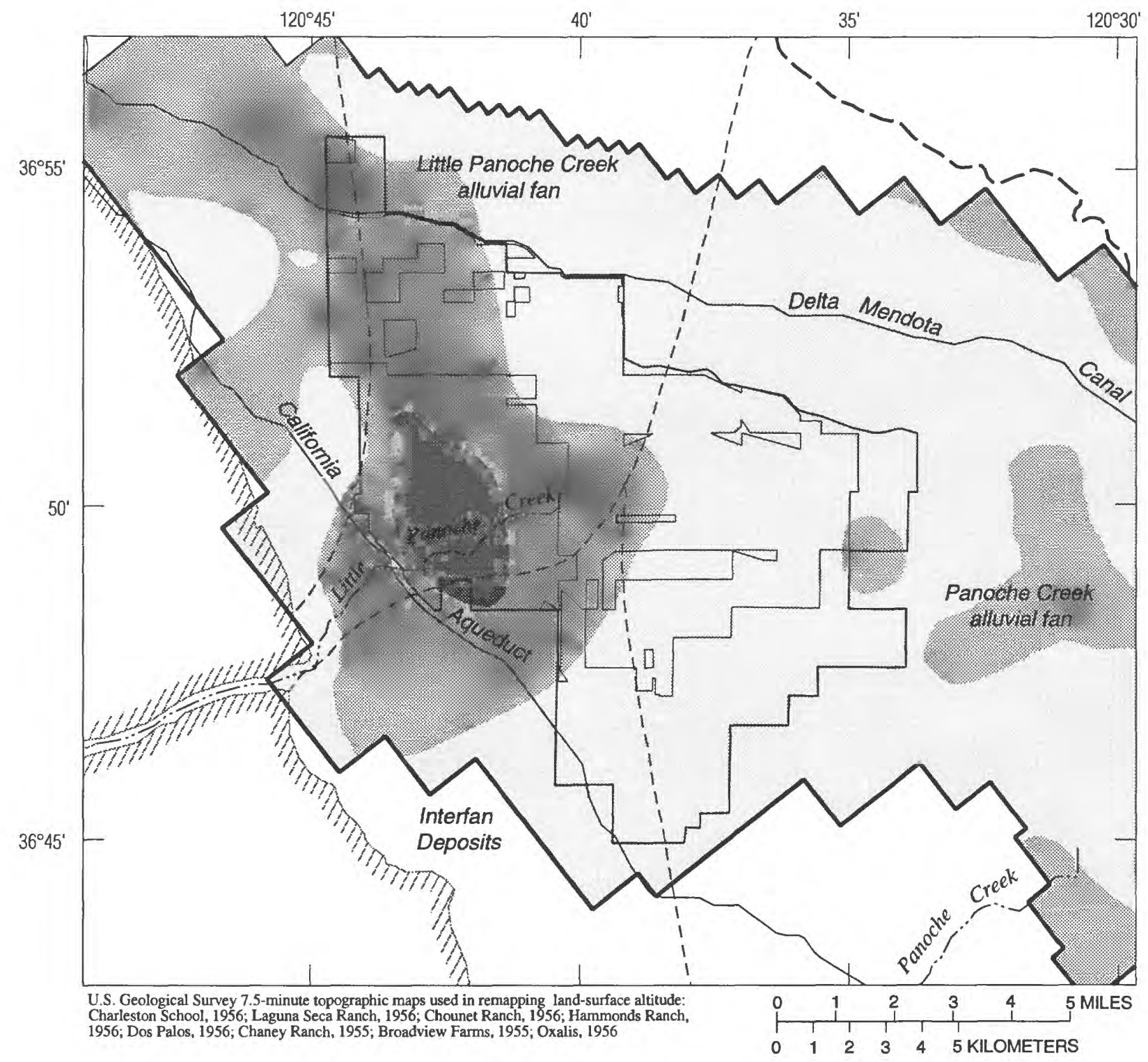

EXPLA NAT ION

FRACTION OF COARSE-GRAINED SEDIMENT Expressed as a percent

$0-25$

$26-50$

$51-75$

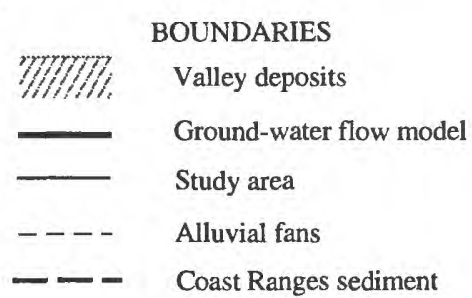

Figure 9. Fraction of coarse-grained sediment in the 0- to 12-meter depth interval. 


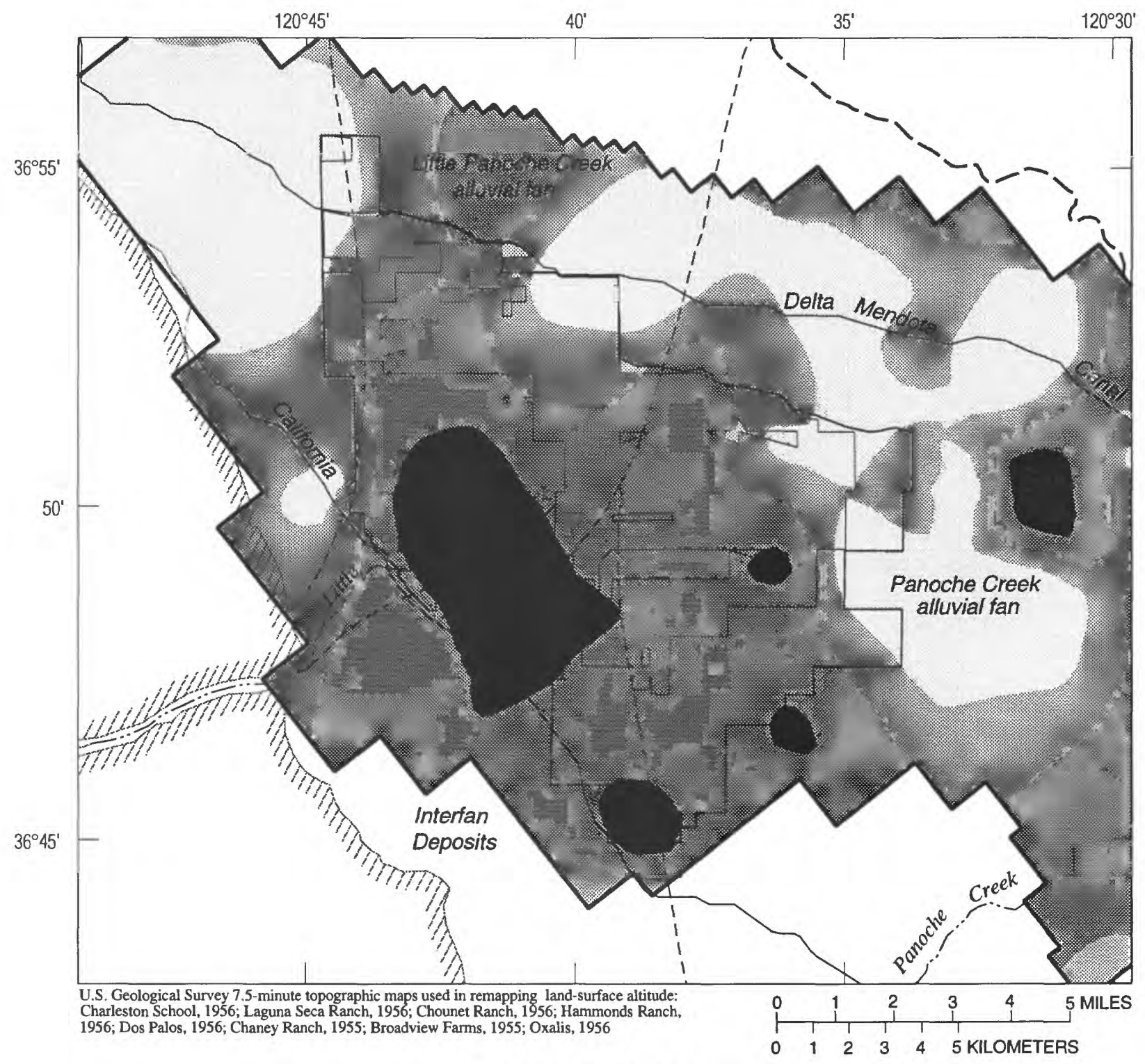

EX P L A N A T I O N

FRACTION OF COARSE-GRAINED SEDIMENT -

$$
\begin{aligned}
& \text { Expressed as a percent } \\
& 0-25 \\
& 26-50 \\
& 51-75 \\
& 76-100
\end{aligned}
$$

\section{BOUNDARIES}

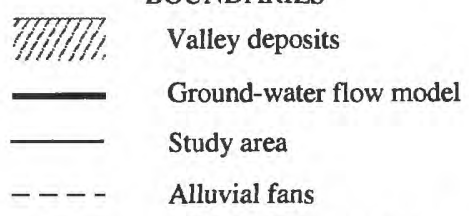

- - Coast Ranges sediment

Figure 10. Fraction of coarse-grained sediment in the 12- to 21-meter deipth interval. 


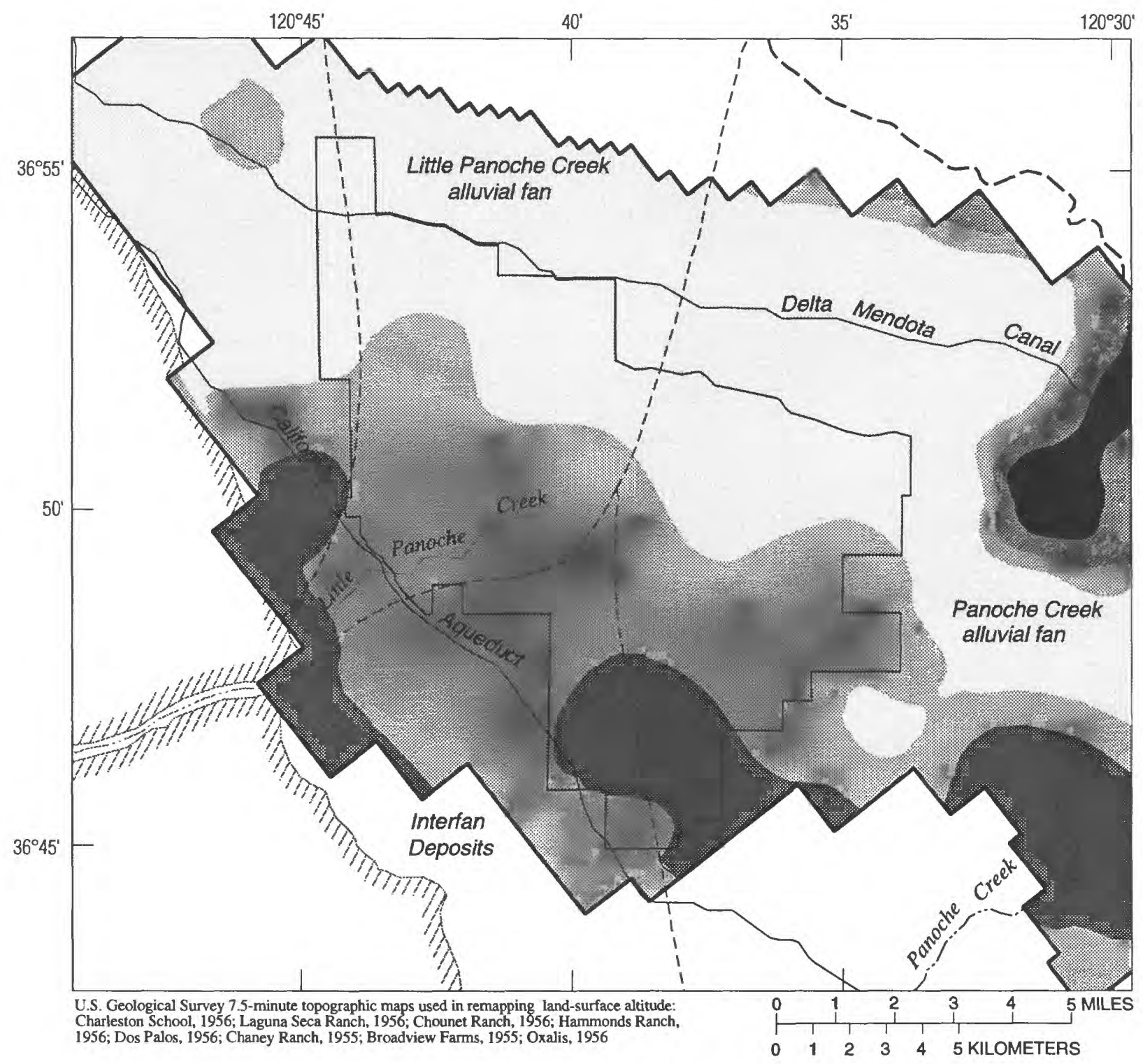

EX P L A N A T I O N

FRACTION OF COARSE-GRAINED SEDIMENT Expressed as a percent

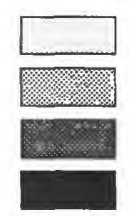
$0-25$
$26-50$
$51-75$
$76-100$

\section{BOUNDARIES}

YYI/1/, Valley deposits

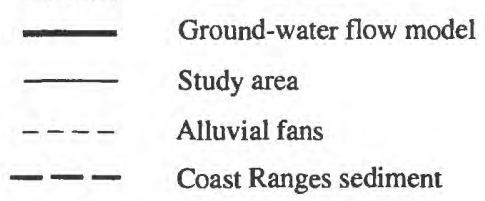

Figure 11. Fraction of coarse-grained sediment in the $21-$ to 30 -meter depth interval. 
margin of the fans. These details are not evident in the texture maps, and the maps are intended only to show general trends in subsurface lithology.

\section{AVERAGE HYDRAULIC HEADS AND DEPTH TO WATER}

Average hydraulic heads and altitude of the water table are projected onto the $A-A^{\prime}, B-B^{\prime}$, and $C-C^{\prime}$ geohydrologic sections in figure 12 . Predominantly coarse-grained sediment near the head of the fans results in substantial depths to water (greater than $3 \mathrm{~m}$ below land surface), but the low-lying areas of the fans are underlain by a relatively shallow water table. The shallow water table gently slopes to the east, paralleling the slope of the land surface. In areas where the water table is at depths greater than $3 \mathrm{~m}$ below land surface, the water table tends to diverge from land surface and slope to the west.

Vertical hydraulic-head gradients between the shallowest and deepest wells range from -0.043 to 0.060 . Gradients that are negative in sign (sites 5 and 6) indicate decreasing heads with depth and downward flow in the upslope areas. Although there is only one observation well at site 2 , data collected during and shortly after well construction indicate that flow is downward. Saturated sediments were first encountered during drilling at site 2 at an altitude of about $68.3 \mathrm{~m}$ above sea level. Two weeks after completion of the observation well, the hydraulic head at a depth of $11.6 \mathrm{~m}$ below the water table was 67.6 $\mathrm{m}$ above sea level, indicating downward flow. In contrast, gradients that are positive in sign (sites 1, 3, and 4) indicate increasing head with depth and upward flow at some locations in the low-lying areas. The vertical component of flow changes with depth at these sites due to heterogeneity in subsurface lithology, ground-water withdrawals by drainage systems, the frequency and intensity of irrigation, and pumping. The gradient at site 7 was small, and the direction of flow was difficult to distinguish from the hydraulic-head data collected at this location.

Figure 13 shows a map of average depth to the water table and the approximate location of a regional ground-water divide identified by Belitz and Heimes (1990). Belitz and Heimes (1990) did not map the divide in the northern part of the study area, and its location in these areas was extrapolated using the data collected during this study. The ground-water divide generally delineates the transition between a westerly trending water table and areas having a water table within $3 \mathrm{~m}$ of land surface. It generally parallels the Coast Ranges, shifting eastward in predominantly coarse-grained sediment at the heads of the alluvial fans and along old stream channels, and shifting westward in predominantly fine-grained sediment at the margins and in between the fanheads (Belitz and Heimes, 1990). Regional drawdowns from deep pumping and greater vertical hydraulic conductivity at the fanheads probably result in the deeper water table and westward flow (Belitz and Heimes, 1990). Ground-water flow east of the divide was downward and toward the northeast. Irrigation water applied to areas east of the divide may move downslope and discharge upward towards the drainage systems from depths as great as $29 \mathrm{~m}$ below land surface.

\section{RECHARGE MEASUREMENTS}

Recharge to the saturated zone was calculated with equation 2 using estimates of water applied, effective precipitation, and consumptive use by crops. Ayars and Schrale (1989) collected this information in the study area for an irrigation efficiency and agricultural drainage study. They compiled 1987 and 1988 data by subareas ranging in area from 0.2 to $50.9 \mathrm{~km}^{2}$; the subareas were selected on the basis of landownership and physical constraints of the waterdelivery system. Consumptive use was estimated with local crop calendars and the total area of specific crops grown in each subarea. Bare-soil evaporation and effective precipitation were estimated from data collected at automated weather stations in and near the study area (California Department of Water Resources, California Irrigation Management System, written commun., 1989). The results from the weather station measurements were then applied uniformly to all the subareas in the study area.

For the purpose of calculating recharge to the saturated zone, the study area was divided into three subareas identified on the basis of measured depth to the water table and drainage conditions (fig. 14): areas where average measured depth to the water table is greater than $3 \mathrm{~m}$ below land surface $\left(36.0 \mathrm{~km}^{2}\right)$; undrained areas where the average depth to water is less than or equal to $3 \mathrm{~m}$ below the land surface $\left(33.5 \mathrm{~km}^{2}\right)$; and drained areas $\left(91.9 \mathrm{~km}^{2}\right)$ where the average depth to water is less than $3 \mathrm{~m}$. (Note that a part of the drained area on the Little Panoche Creek fan is underlain by a water table having an average measured depth greater than $3 \mathrm{~m}$ below land surface.) The results are reported in table 1 , and indicate that recharge to the saturated zone per unit area was similar in the undrained areas $(0.4 \mathrm{~m} / \mathrm{y})$ but less in the drained area $(0.3 \mathrm{~m} / \mathrm{y})$. Less recharge in the drained area is a consequence of smaller quan- 


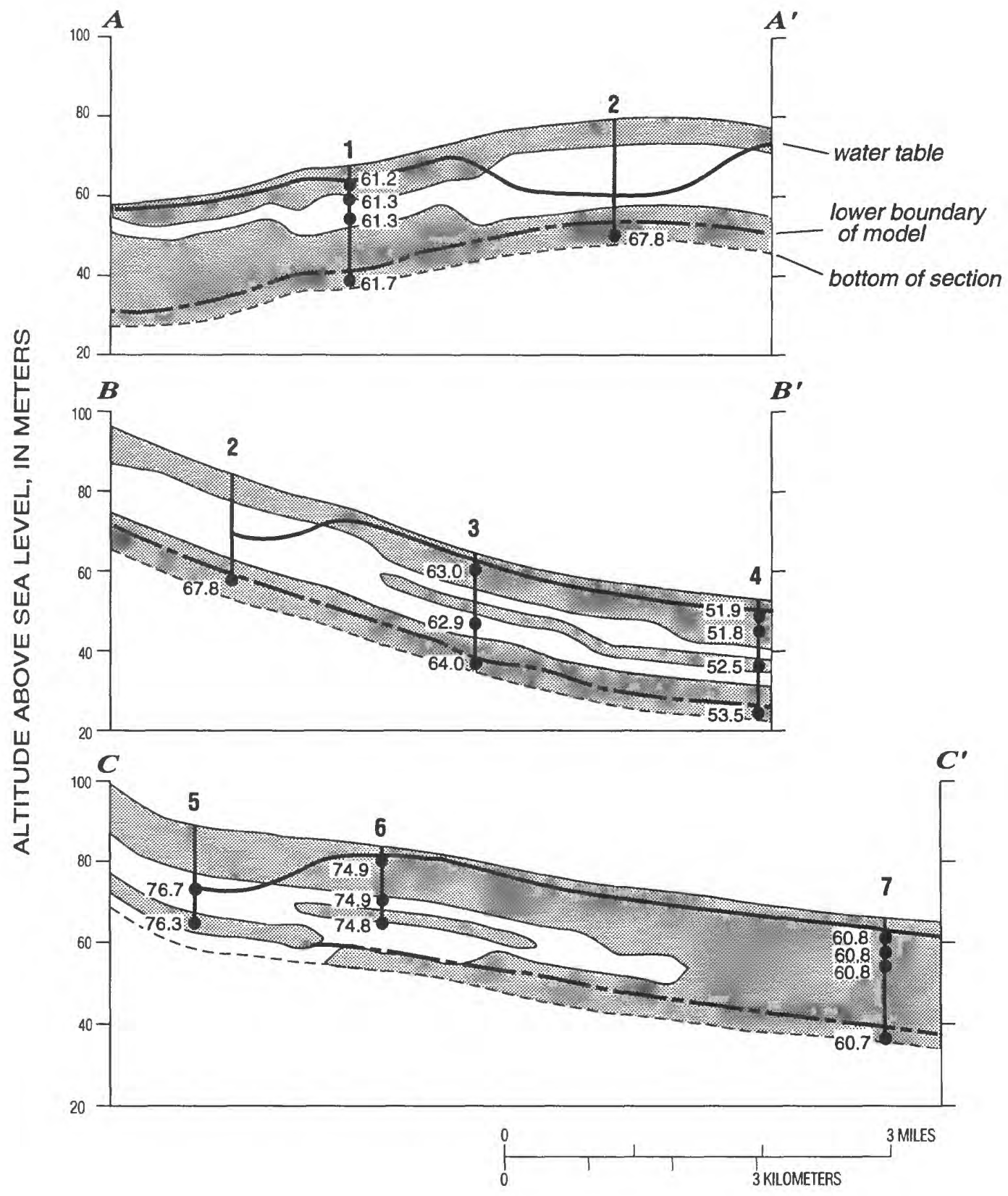

EXPLANATION

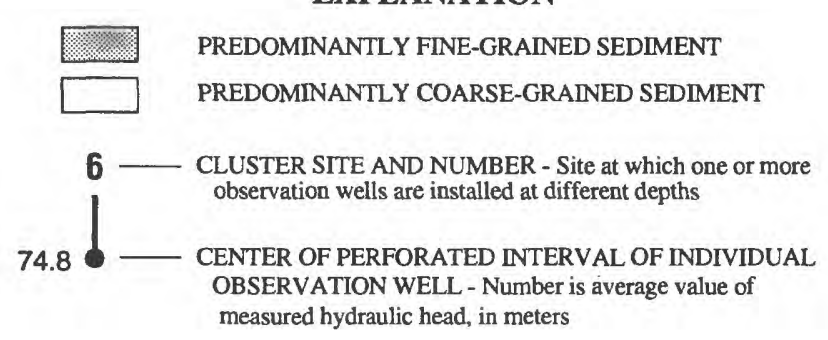

Figure 12. Average hydraulic heads and altitude of the water table projected onto the $A-A^{\prime}, B-B^{\prime}$, and $C-C^{\prime}$ geohydrologic sections. Locations of sections shown in figure 6. 


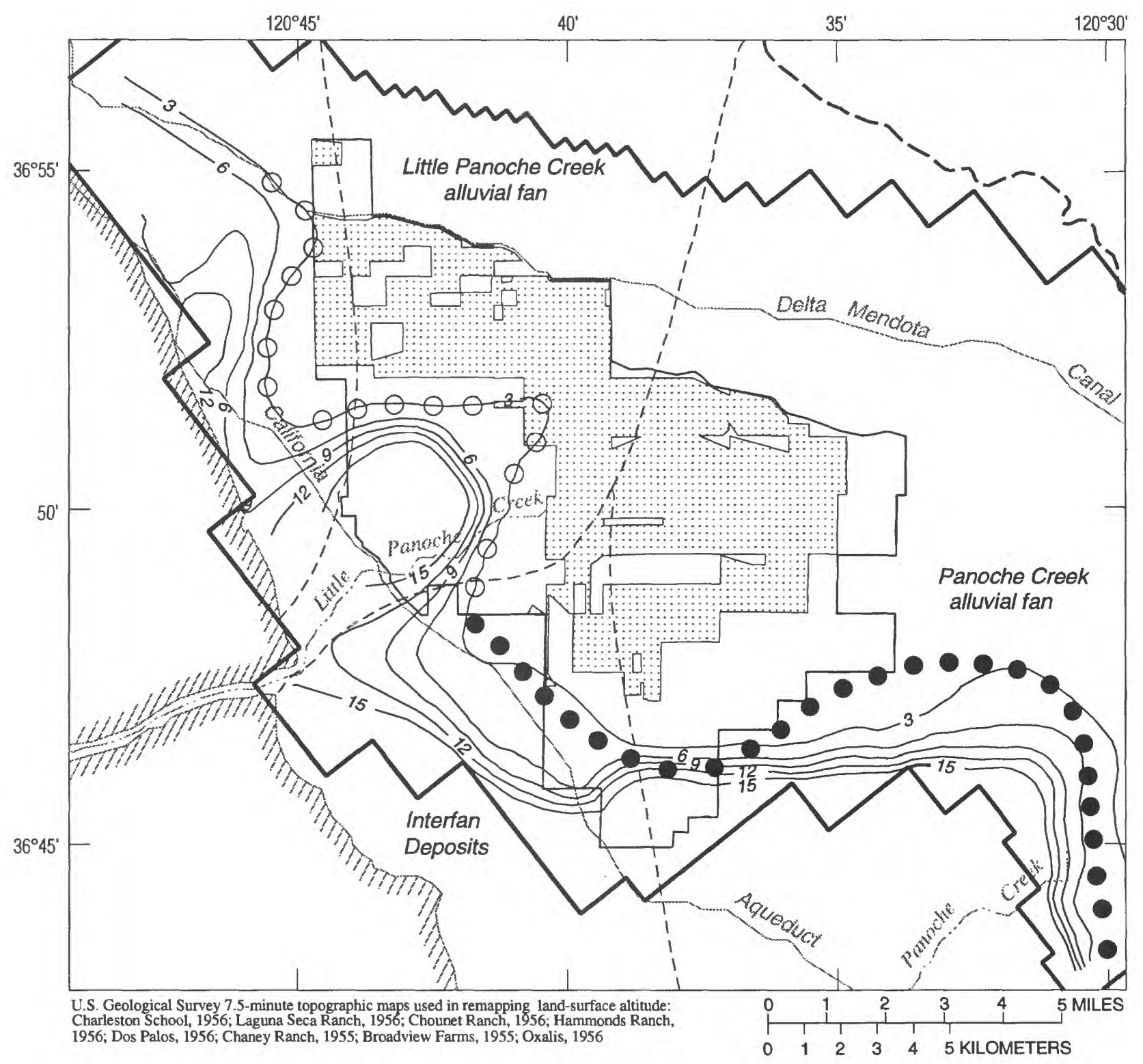

E X P L A N A T I O N

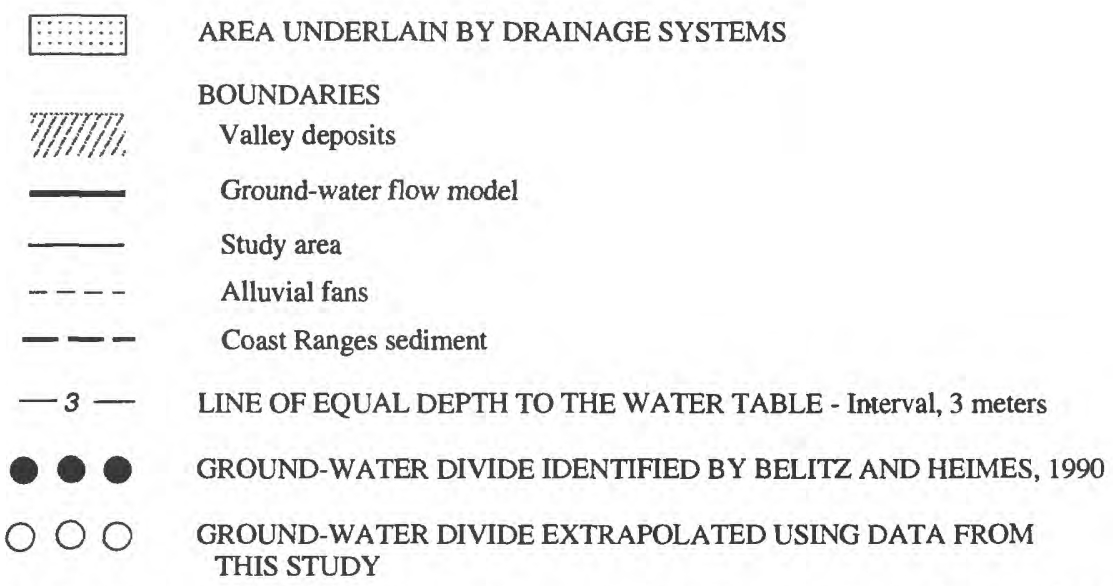

Figure 13. Average depth to the water table and approximate location of a regional ground-water divide (blank areas in study area are undrained; drained areas outside the study area boundaries are not shown). 


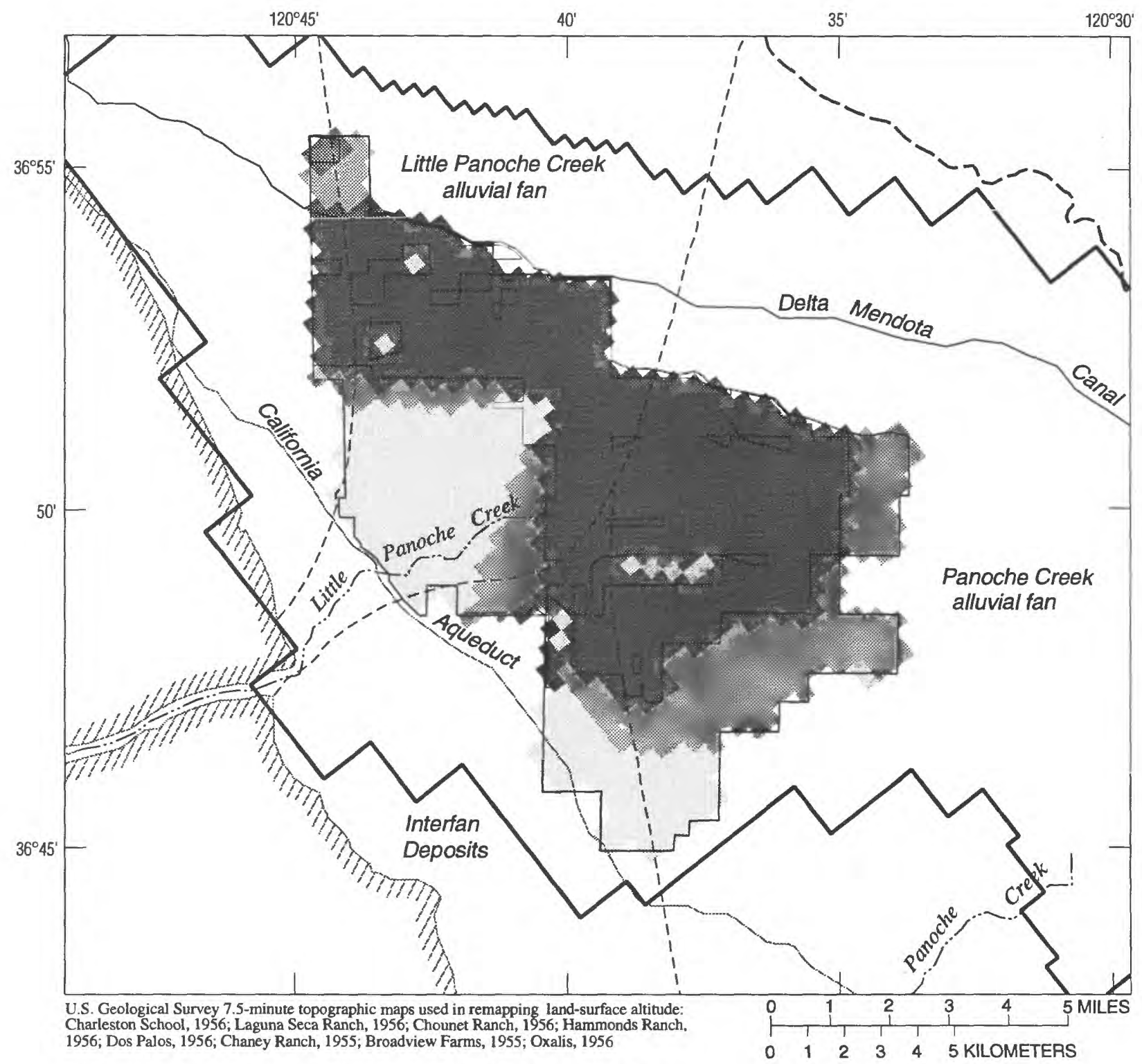

\section{EX PLA NATION}

DEPTH TO WATER TABLE, IN METERS BELOW LAND SURFACE

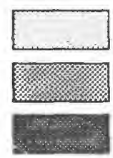

Greater than 3 meters

Less than or equal to 3 meters, undrained

Less than 3 meters, drained
BOUNDARIES

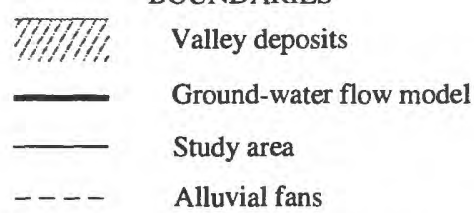

- Coast Ranges sediment

Figure 14. Subareas of the study area, based on average depth to the water table and drainage conditions. 
Table 1. Recharge to the saturated zone for three subareas, calculated as the sum of water applied and effective precipitation less consumptive use

[Average depth to water table in meters below land surface. $\mathrm{km}^{2}$, square kilometer]

\begin{tabular}{|c|c|c|c|c|c|}
\hline \multirow[b]{2}{*}{$\begin{array}{l}\text { Average depth } \\
\text { to water table }\end{array}$} & \multirow[b]{2}{*}{$\begin{array}{l}\text { Area } \\
\left(\mathrm{km}^{2}\right)\end{array}$} & \multicolumn{4}{|c|}{ Values in millions of cubic meters per year } \\
\hline & & $\begin{array}{l}\text { Water } \\
\text { applied } \\
(W a)\end{array}$ & $\begin{array}{c}\text { Effective } \\
\text { precipitation } \\
(P e)\end{array}$ & $\begin{array}{l}\text { Consumptive } \\
\text { use } \\
\text { (C) }\end{array}$ & $\begin{array}{l}\text { Recharge to the } \\
\text { saturated zone } \\
(R)\end{array}$ \\
\hline Greater than 3 meters & 36.0 & 33.1 & 6.8 & 24.8 & 15.1 \\
\hline \multicolumn{6}{|c|}{ Less than or equal to 3 meters } \\
\hline Undrained $\ldots \ldots$ & 33.5 & 29.4 & 6.3 & 21.0 & 14.7 \\
\hline Drained .. & 91.9 & 74.5 & 17.5 & 66.2 & 25.8 \\
\hline Total ... & 161.4 & 137.0 & 30.6 & 112.0 & 55.6 \\
\hline
\end{tabular}

tities applied on a unit area basis and greater consumptive use. Combined recharge for the entire study area was $0.3 \mathrm{~m} / \mathrm{y}$.

The data set of Ayars and Schrale (1989) assumes that the contribution of pumpage to water applied was negligible. Pumping does occur in the study area, but its magnitude and distribution is uncertain. The actual contribution of pumpage to water applied probably varies on an annual basis as a result of changes in surface-water supplies and annual cropping patterns. In 1990, ground-water pumpage measured intermittently at some wells in the study area indicated a minimum withdrawal of $7.0 \times 10^{6} \mathrm{~m}^{3} / \mathrm{y}$ (Panoche Water District, written commun., 1991). The uncertainty in pumpage indicates potential errors in estimates of recharge to the saturated zone, and the addition of pumpage to water applied would result in recharge values greater than those calculated in table 1 .

\section{DRAINFLOW MEASUREMENTS}

Drainflow from the on-farm drainage systems was measured from September 1986 through June 1988 by Panoche Water District using a combination of flowmeters (21 drainage systems), electrical power consumption records from the collector-sump pumps (10 drainage systems), and weir measurements made at selected points along the open channels that receive drainwater and transport it away from the study area
(19 drainage systems). The total drainflow during 1987-88 was $20.8 \times 10^{6} \mathrm{~m}^{3}$ and most of the flow $\left(15.5 \times 10^{6} \mathrm{~m}^{3}\right)$ was discharged during irrigated conditions from February through August; drainflow from September through January represents nonirrigated conditions and was only $5.3 \times 10^{6} \mathrm{~m}^{3}$ (Panoche Water District, written commun., 1989).

On-farm drainflow measured with flowmeters and power-consumption data is plotted in figure 15 (the results from the weir measurements are not included because they often represent drainflow from more than one unmetered drainage system). Linear regression of on-farm drainflows was done to elucidate some of the factors causing variability in drainflow. Results show that flow increased significantly with drain-lateral density ( $p$-value of 0.27 ) and recharge to the saturated zone ( $p$-value of 0.09 ). Drainflow also was significantly correlated to location in the study area relative to the two fans ( $p$-value of 0.05); drainage systems on the Panoche Creek fan generally produce less drainflow than drainage systems on the Little Panoche Creek fan. Linear combination of drain-lateral density, recharge to the saturated zone, and location of drainage system explain about 40 percent of the variability in on-farm drainflow. Additional factors, such as spatial variability in drain-lateral depth and hydraulic conductivity of shallow sediments in the fields, probably contribute to most of the remaining variability (Fio and Deverel, 1991). 


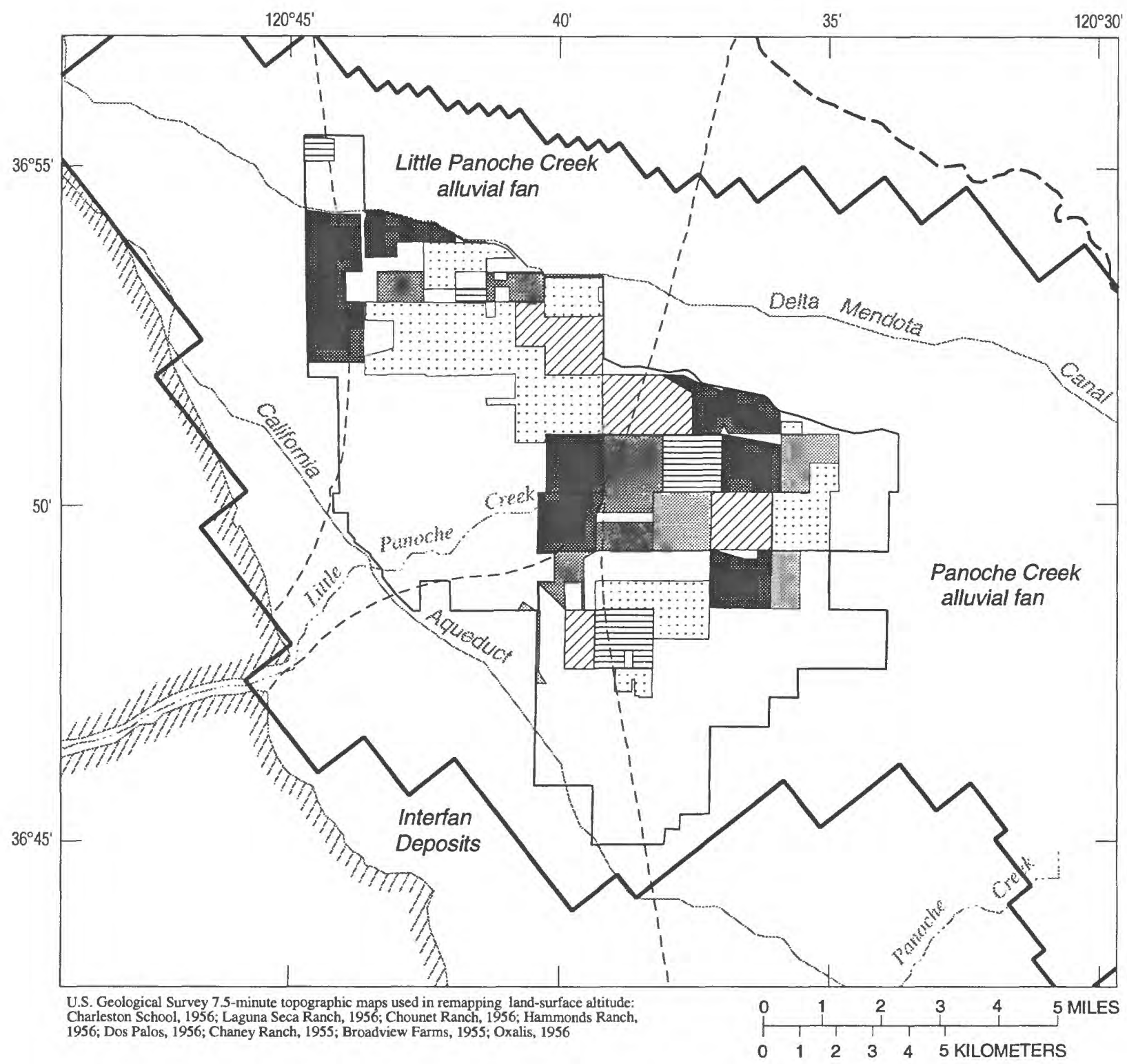

EXPLA NATION

DRAINAGE DISCHARGE $(1,000,000$ cubic meters per acre)

BOUNDARIES

\begin{tabular}{ll}
\hline$\ldots:$ Weir measurements - flow not reported in figure \\
$<0.10$ \\
$0.10-0.20$ \\
$0.21-0.30$ \\
\end{tabular}

恷, $/$ I/, Valley deposits

- Ground-water flow model

- Study area

- - - Alluvial fans

- - Coast Ranges sediment

Figure 15. Areal distribution of on-farm drainflow from flowmeter and electrical power-consumption data (blank areas in study area are undrained; areal distribution of on-farm drainflow in areas outside the study area boundaries is not shown). 


\section{SPECIFICATION OF MODEL INPUT}

\section{MODEL GEOMETRY}

Areally, the model grid is 62 rows by 41 columns; dimensions of model cells vary in length and width (fig. 16). Model cells in the study area are $0.16 \mathrm{~km}^{2}$ and provide detail on lateral flows between the drainage systems. In contrast, model cells between the study area and the model boundaries increase and have a maximum area of $2.59 \mathrm{~km}^{2}$. The larger model cells coincide with the location and dimensions of cells used in the regional model.

A $25.6-\mathrm{m}$ thick interval of aquifer was simulated by the model, and its surface corresponds to the altitude of the calculated water table. Discretization in the vertical direction was selected to provide detail on water-table conditions and ground-water flow to the drainage systems; model layers 1 through 7 are each $3.0 \mathrm{~m}$ thick and layer 8 is $4.6 \mathrm{~m}$ thick. The thickness of model layer 8 is greater to conform with an interval of predominantly fine-grained sediments (fig. 8) coinciding with the lower model boundary. The vertical discretization of the model is such that model layers 1 and 2, 3 through 5, and 6 through 8 coincide with the general depth intervals simulated by the three uppermost layers of the regional model.

\section{BOUNDARY CONDITIONS}

The western and northern boundaries of the model area were treated as no-flow boundaries (fig. 16). The northern part of the western no-flow boundary coincides with the contact between consolidated marine deposits of the Coast Ranges and unconsolidated alluvium to the east. Because the model simulates ground-water hydraulics in the saturated zone, the active cells of the model mesh are truncated along the southern part of the western no-flow boundary so that the uppermost active cells fall approximately at the water table. This boundary of the model represents a flow-line boundary; watertable recharge can move eastward or as deep percolation across the lower boundary of the model. Deep percolation can become westward flow, but is not explicitly simulated by the model. Similarly, the northern no-flow boundary is a flow-line boundary which coincides with the general location of a horizontal flow path inferred from the contours of land-surface elevation and depth to water in figs. 7 and 13, respectively. The horizontal component of flow is generally towards the northeast, and the regional model indicated a flux of $0.7 \mathrm{~m} / \mathrm{y}$ away from the model area and across the eastern boundary (Steven Phillips, U.S. Geological Survey, written commun., 1991). The regional model also indicated that ground water moved into the model area across the southern boundary at a rate of $0.08 \mathrm{~m} / \mathrm{y}$. The regional model results for flow across the eastern and southern boundaries were uniformly distributed in the model developed for this study. Preliminary model runs showed that simulated heads and flow within the study area generally were insensitive to the conditions specified at the model boundaries.

A free-surface boundary was used to simulate the water table, and deep percolation across the lower model boundary was simulated using general-head boundaries (McDonald and Harbaugh, 1988). Recharge to the saturated zone within the study area was specified for the three subareas shown in figure 14 using the results reported in table 1; recharge to areas outside of the study area were identical to the values used in the regional model for similar areas. The general-head boundaries assume deep percolation was proportional to the head difference between the bottom model layer and a prescribed head for a point exterior to the lower model boundary. The proportionality constant, or conductance, was estimated from textural data for depth intervals coinciding with the lower model layer.

The general-head boundaries require specification of the hydraulic-head surface beneath the lower model boundary. The average depth of the deepest wells at the cluster sites is $28.2 \mathrm{~m}$ below land surface, which is $2.3 \mathrm{~m}$ below the bottom model layer. The interpolated distribution of water levels from the deepest wells (fig. 17) was used to calculate the hydraulic-head surface at this depth. Production wells yield ground water from depths considerably greater than $28.2 \mathrm{~m}$, and this head distribution includes the net effect of recharge to areas upslope of the study area and pumping beneath the study area.

The conductance term used for the general-head boundaries is a modified form of Darcys' Law:

$$
C B=K A / L,
$$

where

$C B$ is conductance, in square meters per year;

$K$ is effective hydraulic conductivity in the direction of flow, in meters per year;

$A$ is model cell area perpendicular to flow, in square meters;

$L$ is distance from the boundary to the location of the prescribed hydraulic head, in meters, 


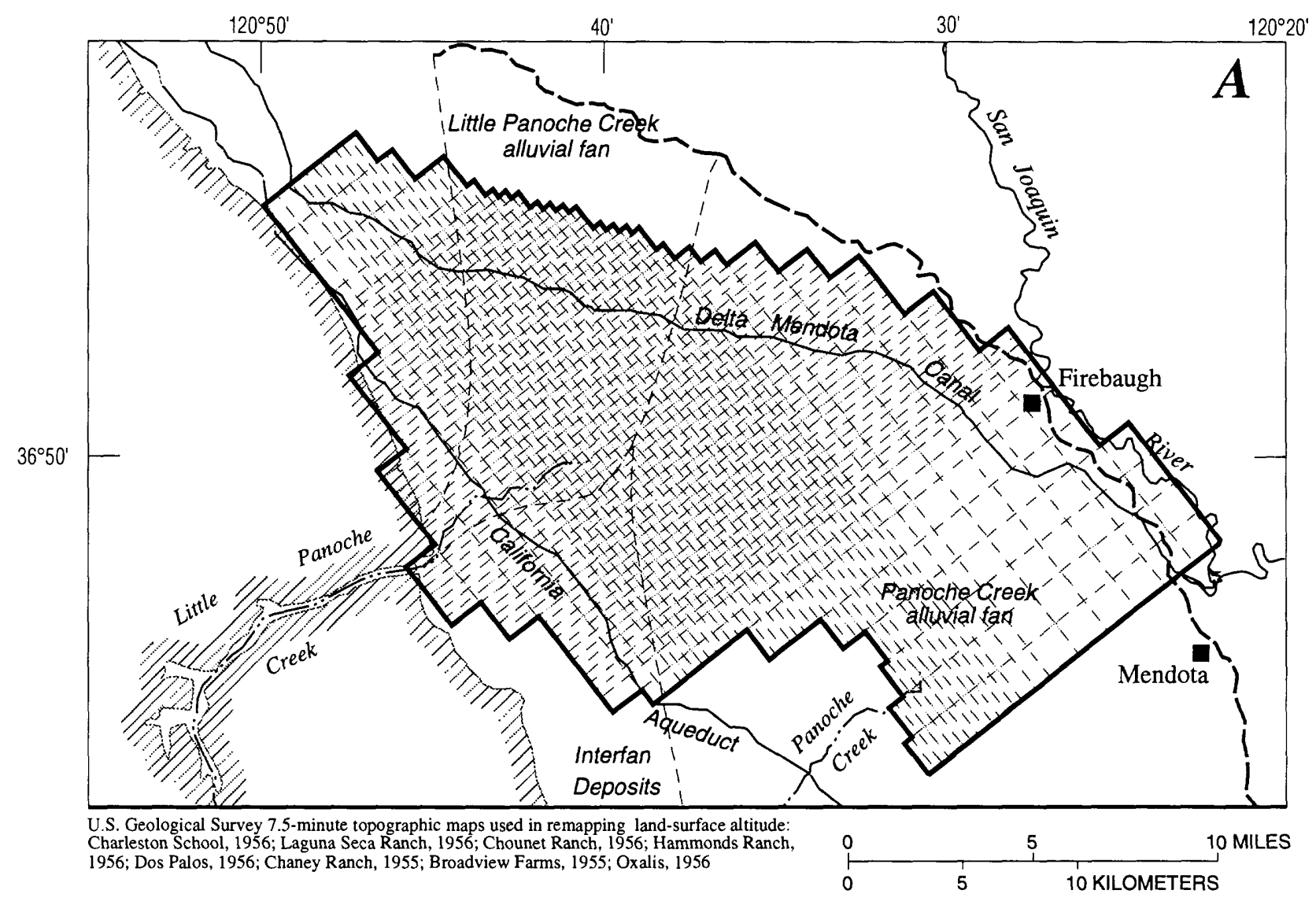

Figure 16. Model grid and boundary conditions (A) and expanded view of grid in study area (B).

and is calculated from the geometry of the generalhead boundary and the textural data. The distance $L$ $(4.6 \mathrm{~m})$ is determined by the midpoint of the lower model layer ( $23.6 \mathrm{~m}$ below land surface) and the average depth of the hydraulic-head surface $(28.2 \mathrm{~m})$. The effective hydraulic conductivity was calculated from the equivalent hydraulic conductivity of the depth interval between the two points defining the distance $L$

\section{BARE-SOIL EVAPORATION FROM THEORETICAL CONSIDERATIONS}

Bare-soil evaporation is assumed constant $\left(E_{\max }\right)$ if the water table (or hydraulic head) in the top model layer is at or above a reference surface $\left(Z_{\text {surf }}\right)$. The evaporation rate is zero when the water table is a specified depth below $Z_{\text {surf }}$ (the extinction depth, $D_{e x t}$ ). If the water table is between $Z_{\text {surf }}$ and $D_{\text {ext }}$, the evaporation rate decreases in a linear fashion from the maximum rate to zero (McDonald and Harbaugh, 1988):

$$
\begin{array}{r}
E=E_{\max } \cdot\left[h-\left(Z_{\text {surf }}^{\prime}-D_{\text {ext }}\right)\right] / D_{\text {ext }} \\
\text { if } Z_{\text {surf }}-D_{\text {ext }}>h>Z_{\text {ref }} .
\end{array}
$$

Belitz and others (1992) used a theoretical analysis of bare-soil evaporation and soil data for Panoche Clay loam (Nielson and others, 1973) to estimate $E_{\max }$ and the linear function describing evaporation. Their analysis resulted in a maximum evaporation rate of $0.3 \mathrm{~m} / \mathrm{y}$ at or above a depth of $1.2 \mathrm{~m}$ below land surface. The regional model was sensitive to the extinction depth, and Belitz and others (1992) reported that a value of $2.1 \mathrm{~m}$ below land surface was most consistent with the theoretical analysis and the simulated number of model cells subject to bare-soil evaporation estimated from the synthesis of more than 6,000 space-time data points. The values used in the regional model also were used in this study.

\section{DRAINFLOW CONDUCTANCE TERMS CALCULATED WITH DRAIN-LATERAL DENSITIES}

Drainflow is assumed to be proportional to the hydraulic-head gradient between ground water in the model cell and ground water in the drain laterals; drainflow is zero if the hydraulic head in the model cell is at or lower than the drain lateral (McDonald and Harbaugh, 1988): 


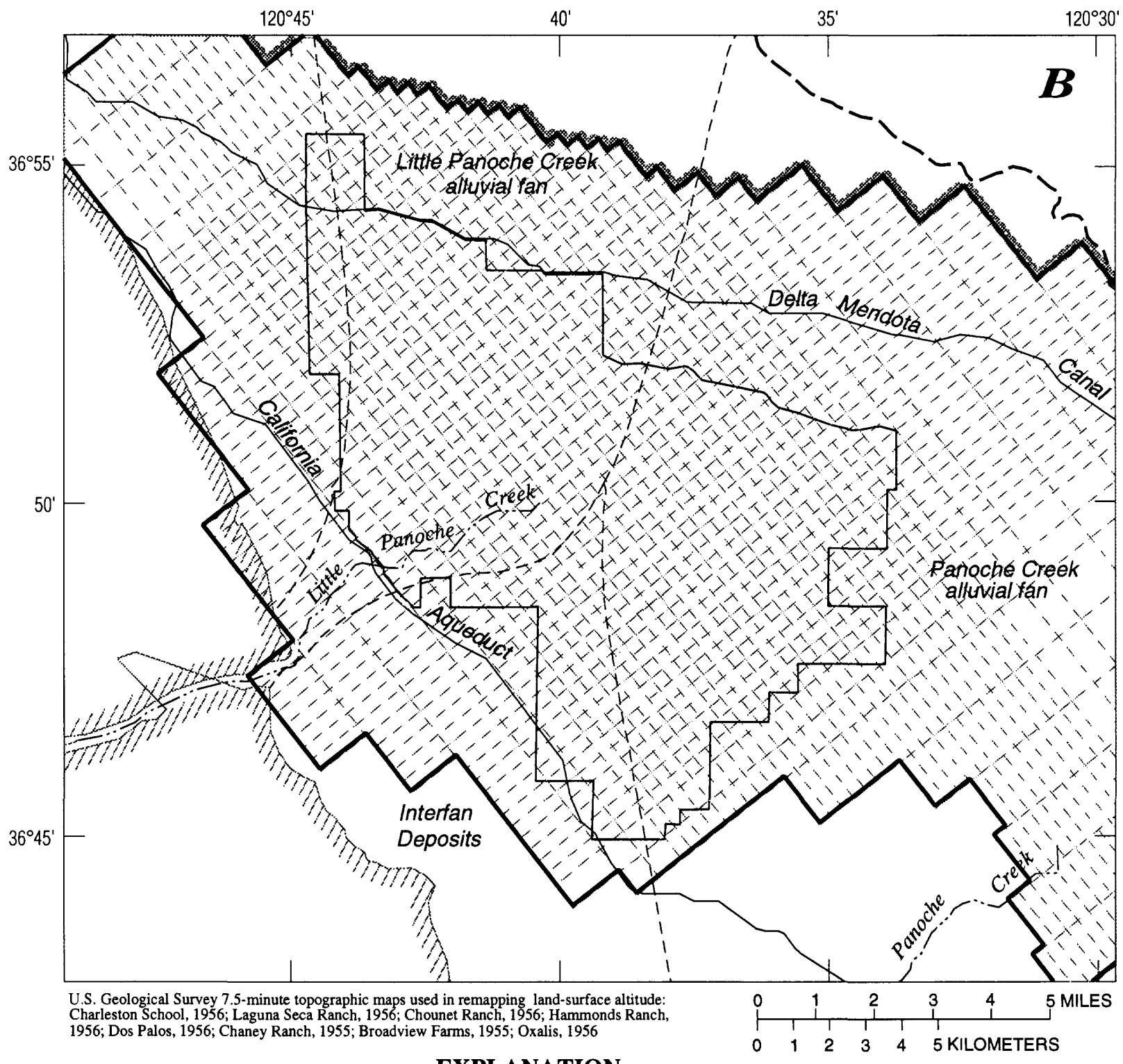

\section{EXPLANATION}

MODEL GRID - Dimensions of cells vary in length and width
Salley deposits
Alluvial fans
Coast Ranges sediment
MODEL BOUNDARIES
No flow
Specified flow

Figure 16. Continued. 


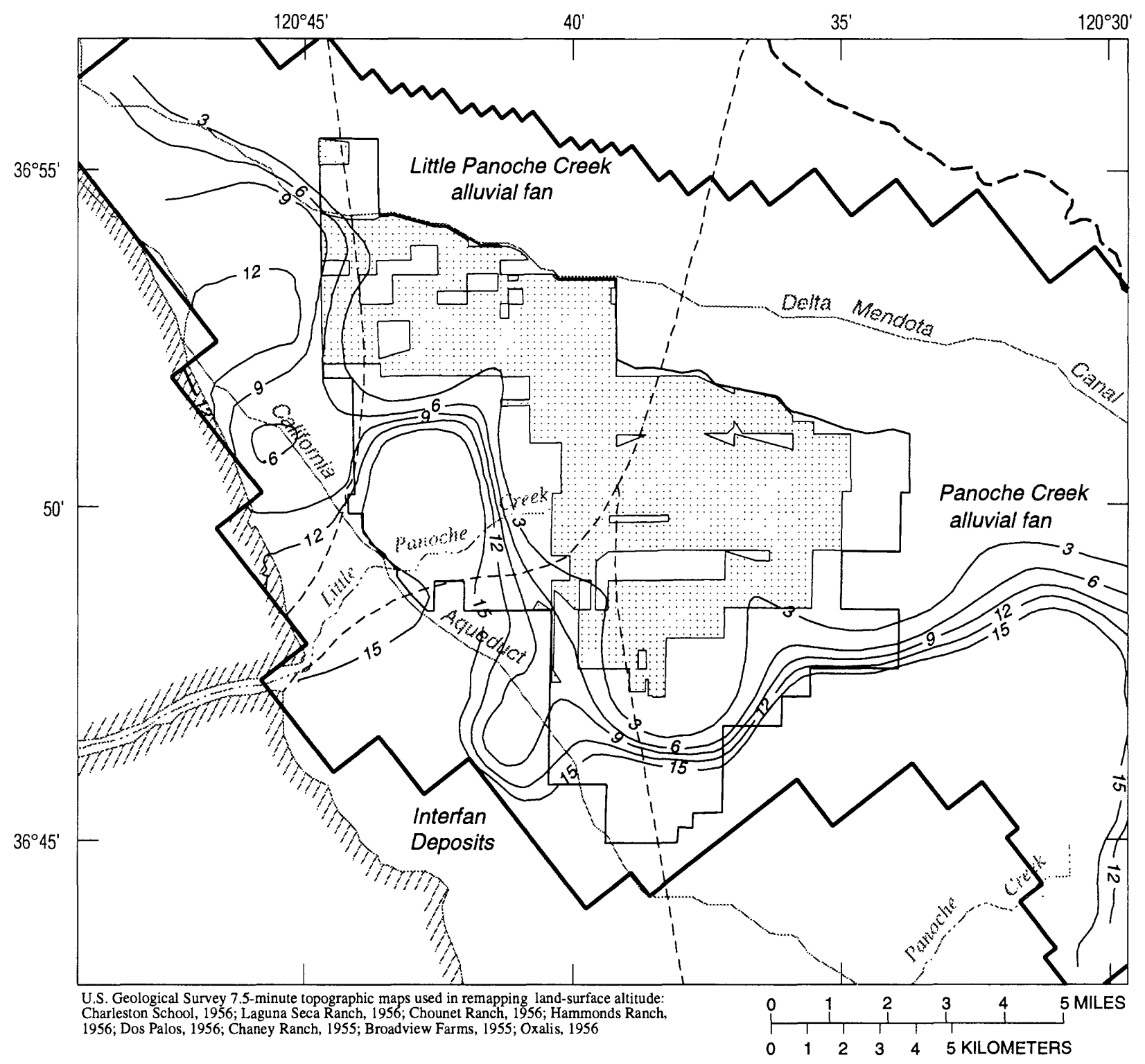

\section{E X P L A N A T I O N}

AREA UNDERLAIN BY DRAINAGE SYSTEMS

BOUNDARIES

TI!I!', $\quad$ Valley deposits

- Ground-water flow model

Study area

- - - Alluvial fans

- - Coast Ranges sediment

- 9 - LINE OF EQUAL DEPTH TO WATER IN OBSERVATION WELLS Interval, 3 meters

Figure 17. Average depth to water in the wells perforated below the bottom model layer (blank areas in study area are undrained; drained areas outside the study area boundaries are not shown). 


$$
Q d=C\left(H_{\text {drain }}-H_{m}\right)
$$

where

$C$ is proportionality constant, or drain conductance for simulating drainflow, in square meters per year;

$H_{\text {drain }}$ is mean or effective hydraulic head in the drain laterals, in meters; and

$H_{m}$ is hydraulic head in the model cell, in meters.

Drain conductance controls drainflow by accounting for the effects of head losses due to flow through the aquifer between drain laterals, backfill materials around the drain laterals, the wall of the drain laterals, and convergence of flow at the drain laterals (McDonald and Harbaugh, 1988).

Most model cells simulate flow to more than one drain lateral, and specified hydraulic head in the drain laterals represents an effective head for the drainage system simulated by the model cell. Drain laterals are normally partly full of water (Fio and Deverel, 1991), and the hydraulic head in the drains is assumed to be about equal to their altitude. Data were not available to determine the effective altitude of the drain laterals for all drainage systems, but data indicate that the depths range from 1.8 to $2.7 \mathrm{~m}$ below land surface (mean depth of $2.3 \mathrm{~m}$ below land surface). This generally agrees with the value of 2.2 $\mathrm{m}$ below land surface used in the regional model, and thus $2.2 \mathrm{~m}$ below land surface also was used in this model.

Adequate specification of drain conductance requires consideration of the length of drain laterals in the model cell (product of drain-lateral density and model-cell area), the effective hydraulic conductivity of the drain laterals, and hydraulic conductivity of aquifer materials between the drains:

$$
C=k_{d} * p_{d} * A_{m},
$$

where

$k_{d}$ is effective hydraulic conductivity of the drain/ aquifer system, in meters per year,

$p_{d}$ is drain-lateral density, in meters per square kilometer, and

$A_{m}$ is area of the model cell, in square kilometers.

The effective hydraulic conductivity of the drain/aquifer system was difficult to quantify because of differences in drain-lateral materials and spatial variability in hydraulic conductivity between drain laterals. Drain conductance values in the regional model and field model were used to provide approximate values for drainage systems in the study area.

Belitz and others (1992) estimated drain conductance for on-farm drainage systems in the northern part of the regional model using linear regression of water levels and flow data from three fields. Two of the fields are in the study area and are on the Little Panoche Creek fan, and the third is about $3 \mathrm{~km}$ east of the study area on the Panoche Creek fan. Drain-lateral densities in the three fields were $8,900,7,600$, and $10,800 \mathrm{~m} / \mathrm{km}^{2}$, respectively (Lord, 1988). Linear regression conducted by Belitz and others (1992) indicated drain conductance values for these fields of $1.9,1.8$, and $0.9 \times 10^{6} \mathrm{~m}^{2} / \mathrm{y}$, respectively. Note that drain conductance values for the two fields on the Little Panoche Creek fan are about twice the magnitude of the conductance values calculated for the field on the Panoche Creek fan. The model cells in the regional model have areas of $2.59 \mathrm{~km}^{2}$, and equation 13 gives effective conductivity values for the drain/aquifer system in these fields of 82,91 , and $32 \mathrm{~m} / \mathrm{y}$. The results for the two fields on the Little Panoche Creek fan generally agree with results reported by Fio and Deverel (1991), indicating that the effective conductivity of a unit length of drain/aquifer system in one field is $100 \mathrm{~m} / \mathrm{y}$. Because most of the drainflow comes from fields on the Little Panoche Creek fan, the model uses $100 \mathrm{~m} / \mathrm{y}$ in equation 13 to calculate drain conductance.

\section{EQUIVALENT HYDRAULIC CONDUCTIVITY AND MODEL ASSESSMENT}

Equivalent hydraulic conductivity was calculated for input to the model using endmember hydraulic conductivities for coarse- and fine-grained sediment and the textural distribution determined from lithologic data. The weighted arithmetic average was used to calculate equivalent hydraulic conductivity in the horizontal direction, and model results were used to assess the weighted geometric and harmonic averaging techniques to calculate equivalent hydraulic conductivity in the vertical direction. On the average, the resulting anisotropy using the harmonic average was 1:1,670; whereas, anisotropy using the geometric average was 1:125 (anisotropy in the model was calculated from the ratio of equivalent hydraulic conductivity in the vertical and horizontal directions).

Model results and measured data are reported in table 2. The BIAS calculated between annual heads and simulated head using the geometric and har- 
Table 2. Simulated hydraulic heads, drainflow, and bare-soil evaporation using vertical model cell conductances calculated by geometric and harmonic averaging techniques and measured or estimated from field data

$\left[\mathrm{m}\right.$, meter; $\mathrm{m}^{3} / \mathrm{y}$, cubic meter per year]

\begin{tabular}{|c|c|c|c|c|c|c|}
\hline \multirow{2}{*}{$\begin{array}{l}\text { Cluster } \\
\text { site }\end{array}$} & \multirow{2}{*}{$\begin{array}{l}\text { Depth to } \\
\text { center of } \\
\text { perforated } \\
\text { interval } \\
\text { (m) }\end{array}$} & \multicolumn{3}{|c|}{$\begin{array}{l}\text { Average measured } \\
\text { hydraulic head }(m)\end{array}$} & \multicolumn{2}{|c|}{$\begin{array}{c}\text { Simulated hydraulic } \\
\text { heads (m) }\end{array}$} \\
\hline & & $\begin{array}{c}\text { Irrigated } \\
\text { February- } \\
\text { August }\end{array}$ & $\begin{array}{l}\text { Nonirrigated } \\
\text { September- } \\
\text { January }\end{array}$ & $\begin{array}{l}\text { Annual } \\
\text { February- } \\
\text { January }\end{array}$ & $\frac{1}{\text { Geometric }}$ & Harmonic \\
\hline 1 & $\begin{array}{r}5.0 \\
8.4 \\
13.5\end{array}$ & $\begin{array}{l}61.5 \\
61.6 \\
61.6\end{array}$ & $\begin{array}{l}60.9 \\
60.9 \\
60.9\end{array}$ & $\begin{array}{l}61.2 \\
61.3 \\
61.3\end{array}$ & $\begin{array}{l}62.0 \\
61.7 \\
61.7\end{array}$ & $\begin{array}{l}62.3 \\
62.0 \\
61.9\end{array}$ \\
\hline 3 & $\begin{array}{r}4.9 \\
17.2\end{array}$ & $\begin{array}{l}63.2 \\
63.2\end{array}$ & $\begin{array}{l}62.8 \\
62.7\end{array}$ & $\begin{array}{l}63.0 \\
62.9\end{array}$ & $\begin{array}{l}64.1 \\
64.1\end{array}$ & $\begin{array}{l}64.7 \\
64.5\end{array}$ \\
\hline 4 & $\begin{array}{r}4.0 \\
8.3 \\
17.2\end{array}$ & $\begin{array}{l}52.0 \\
51.9 \\
52.5\end{array}$ & $\begin{array}{l}51.8 \\
51.8 \\
52.5\end{array}$ & $\begin{array}{l}51.9 \\
51.8 \\
52.5\end{array}$ & $\begin{array}{l}52.0 \\
52.3 \\
52.6\end{array}$ & $\begin{array}{l}52.0 \\
52.3 \\
52.7\end{array}$ \\
\hline 5 & 17.4 & 76.5 & 76.8 & 76.7 & 77.2 & 81.1 \\
\hline 6 & $\begin{array}{r}3.8 \\
13.0 \\
19.4\end{array}$ & $\begin{array}{l}75.2 \\
75.2 \\
75.0\end{array}$ & $\begin{array}{l}74.7 \\
74.7 \\
74.6\end{array}$ & $\begin{array}{l}74.9 \\
74.9 \\
74.8\end{array}$ & $\begin{array}{l}75.1 \\
74.5 \\
74.5\end{array}$ & $\begin{array}{l}75.6 \\
75.2 \\
75.0\end{array}$ \\
\hline 7 & $\begin{array}{r}5.2 \\
6.8 \\
11.4\end{array}$ & $\begin{array}{l}61.1 \\
61.2 \\
61.1\end{array}$ & $\begin{array}{l}60.5 \\
60.5 \\
60.5\end{array}$ & $\begin{array}{l}60.8 \\
60.8 \\
60.8\end{array}$ & $\begin{array}{l}62.2 \\
62.1 \\
62.1\end{array}$ & $\begin{array}{l}63.3 \\
62.8 \\
62.6\end{array}$ \\
\hline $\begin{array}{r}\text { Drainflo } \\
\text { (in } 1,0\end{array}$ & $\left.\mathrm{~m}^{3} / \mathrm{y}\right)$ & 15.5 & 5.3 & 20.8 & 20.8 & 22.8 \\
\hline $\begin{array}{l}\text { Bare-soil } \\
\text { (in } 1,0\end{array}$ & $\begin{array}{c}\text { oration } \\
\left.\mathrm{m}^{3} / \mathrm{y}\right)\end{array}$ & -- & -- & 11.3 & 10.3 & 14.2 \\
\hline
\end{tabular}

monic averaging techniques are -8.6 and $-18.4 \mathrm{~m}$, respectively. Negative values of the BIAS indicate that simulated heads generally are greater than average heads, and further inspection of table 2 shows general agreement between simulated heads and average conditions measured during the irrigated season. The negative BIAS probably results from limitations of the steady-state modeling assumption. The time scale of individual irrigation events is about 1 week, but recharge to the saturated zone is simulated as a relatively long-term annual event. The model thus incorporates recharge from several irrigations into a single event averaged over the entire year. In contrast, hydraulic heads measured on a biweekly basis tend to represent drainage conditions in between irrigation events and during the nonirrigated season.

On the average, better agreement exists between simulated and measured heads using the geometric average (RMSE of $0.8 \mathrm{~m}$ and $1.7 \mathrm{~m}$, respectively).
The deviation between the two techniques was greatest at site 5 ; site 5 is relatively high on the alluvial fan and underlain by substantial quantities of coarse-grained sediment (fig. 8). The harmonic average excessively weights the fine-grained endmember in these upslope areas relative to the geometric average, and thus excessively restricts downward flow.

Estimates of bare-soil evaporation in the study area using automated weather stations indicate a flux of about $0.09 \mathrm{~m} / \mathrm{y}$ (Ayars and Schrale, 1989). Assuming that bare-soil evaporation is limited to areas having a water table within $3 \mathrm{~m}$ of land surface $\left(125.4 \mathrm{~km}^{2}\right.$ in table 1$)$, about $11.3 \times 10^{6} \mathrm{~m}^{3}$ of ground water is removed from the study area on an annual basis by bare-soil evaporation. Theoretical considerations and regional model results indicate that baresoil evaporation is limited to areas having a water table within $2.1 \mathrm{~m}$ of land surface (Belitz and others, 
1992), thus bare-soil evaporation in the study area probably is less than $11.3 \times 10^{6} \mathrm{~m}^{3} / \mathrm{y}$. Simulated baresoil evaporation using the geometric average $\left(10.3 \times 10^{6} \mathrm{~m}^{3} / \mathrm{y}\right)$ is about 9 percent less than estimated, but simulated bare-soil evaporation using the harmonic average $\left(14.2 \times 10^{6} \mathrm{~m}^{3} / \mathrm{y}\right)$ is about 26 percent greater than estimated. Similarly, simulated drainflow using the harmonic average $\left(22.8 \times 10^{6} \mathrm{~m}^{3} / \mathrm{y}\right)$ is about 10 percent greater than measured $\left(20.8 \times 10^{6} \mathrm{~m}^{3} / \mathrm{y}\right)$; simulated drainflow using the geometric average agreed with measured drainflow. Based on the above comparison between simulated hydraulic heads, baresoil evaporation, and drainflow, the results using the geometric averaging technique were used for further analyses to calculate the water budget and delineate drainflow sources.

\section{CONTRIBUTING SOURCES TO DRAINFLOW}

The model was used to calculate the water budget for three subareas: areas having a water table greater than $3 \mathrm{~m}$ below land surface, undrained areas having an average depth to the water table within $3 \mathrm{~m}$ of land surface, and drained areas having an average depth to the water table within $3 \mathrm{~m}$ of land surface (table 3). Deep percolation across the lower model layer is greatest in the upslope areas, where the average depth to the water table is greater than $3 \mathrm{~m}$ below land surface and bare-soil evaporation and drainflow are absent $\left(-17.4 \times 10^{6} \mathrm{~m}^{3} / \mathrm{y}\right)$. In contrast, deep percolation is smallest in the drained area $\left(-3.8 \times 10^{6} \mathrm{~m}^{3} / \mathrm{y}\right)$, where drainage systems intercept and discharge large quantities of water $\left(20.8 \times 10^{6} \mathrm{~m}^{3} / \mathrm{y}\right)$. Net ground-water recharge, calculated as recharge to the saturated zone less bare-soil evaporation and drainflow, is $24.5 \times 10^{6} \mathrm{~m}^{3} / \mathrm{y}$ for the entire study area.
Though significant quantities of recharge are removed by evaporation and drainflow, the positive value of net ground-water recharge indicates that irrigation represents a net addition of water to the ground-water flow system.

Net ground-water recharge contributes to deep percolation across the lower model layer. The subarea having an average depth to the water table that is greater than $3 \mathrm{~m}$ below land surface is of particular interest because deep percolation in this subarea was actually greater than net ground-water recharge. Eastward flowing ground water originating upslope of the study area contributed $1.4 \times 10^{6} \mathrm{~m}^{3} / \mathrm{y}$ of deep percolation beneath this subarea, but these eastward flows must be interpreted with caution because geohydrologic data for areas upslope of the study area are limited. Westward flowing ground water originating within the undrained areas that have an average depth to the water table within $3 \mathrm{~m}$ of land surface contributed $0.9 \times 10^{6} \mathrm{~m}^{3} / \mathrm{y}$ of deep percolation beneath the subarea having a deeper water table; $3.0 \times 10^{6} \mathrm{~m}^{3} / \mathrm{y}$ of lateral-flowing ground water moves from the undrained subarea into the drained subarea. The groundwater divide in the undrained area delineates the transition between these westward and eastward flows.

Particle tracking shows that a substantial area of the drainage systems intercept lateral-flowing ground water and upward-moving deep percolation (fig. 18), and thus sources of drainflow in many fields are complex. The water budget was calculated for the parts of the drained area delineated in figure 18 to evaluate the contribution of regional ground water to drainflow (table 4). For the purposes of calculating a water budget, lateral-flowing ground water and upward-moving deep percolation are assumed to

Table 3. Annual water budget for three subareas

[Positive quantities represent additions to the water budget and drainflow, whereas negative quantities represent subtractions from the water budget and reductions to drainflow. $\mathrm{km}^{2}$, square kilometer]

\begin{tabular}{|c|c|c|c|c|c|c|}
\hline \multirow[b]{2}{*}{$\begin{array}{l}\text { Average depth } \\
\text { to water table }\end{array}$} & \multirow[b]{2}{*}{$\begin{array}{l}\text { Area } \\
\left(\mathrm{km}^{2}\right)\end{array}$} & \multicolumn{5}{|c|}{ Values in millions of cubic meters per year } \\
\hline & & $\begin{array}{l}\text { Recharge to the } \\
\text { saturated zone } \\
(R)\end{array}$ & $\begin{array}{c}\text { Bare-soil } \\
\text { evaporation } \\
(E)\end{array}$ & $\begin{array}{l}\text { Lateral ground- } \\
\text { water flow } \\
(G l)\end{array}$ & $\begin{array}{c}\text { Deep } \\
\text { percolation } \\
(D p)\end{array}$ & $\begin{array}{l}\text { Drain- } \\
\text { flow } \\
(Q d) \\
\end{array}$ \\
\hline Greater than 3 meters & 36.0 & 15.1 & 0 & 2.3 & -17.4 & 0 \\
\hline \multicolumn{7}{|c|}{ Less than or equal to 3 meters } \\
\hline Undrained $\ldots \ldots$ & 33.5 & 14.7 & -6.1 & -3.9 & -4.7 & 0 \\
\hline Drained & 91.9 & 25.8 & -4.2 & 3.0 & -3.8 & 20.8 \\
\hline Total & 161.4 & 55.6 & -10.3 & 1.4 & -25.9 & 20.8 \\
\hline
\end{tabular}


Table 4. Annual water budget for subareas of the drainage systems

[Positive quantities represent additions to the water budget and drainflow, whereas negative quantities represent subtractions from water budget and reductions to drainflow. $\mathrm{km}^{2}$, square kilometer]

\begin{tabular}{|c|c|c|c|c|c|c|}
\hline \multirow[b]{2}{*}{$\begin{array}{l}\text { Source of } \\
\text { drainflow }\end{array}$} & \multirow[b]{2}{*}{$\begin{array}{l}\text { Area } \\
\left(\mathrm{km}^{2}\right)\end{array}$} & \multicolumn{5}{|c|}{ Values in millions of cubic meters per year } \\
\hline & & $\begin{array}{l}\text { Recharge to the } \\
\text { saturated zone } \\
(R)\end{array}$ & $\begin{array}{c}\text { Bare-soil } \\
\text { evaporation } \\
(E)\end{array}$ & $\begin{array}{l}\text { Lateral ground- } \\
\text { water flow } \\
(G l)\end{array}$ & $\begin{array}{c}\text { Deep } \\
\text { percolation } \\
(D p)\end{array}$ & $\begin{array}{l}\text { Drain- } \\
\text { flow } \\
(Q d)\end{array}$ \\
\hline $\begin{array}{l}\text { Recharge to the } \\
\text { saturated zone }\end{array}$ & 49.7 & 13.9 & -2.3 & 1.2 & -4.3 & 8.5 \\
\hline $\begin{array}{l}\text { and lateral-flowing } \\
\text { ground water }\end{array}$ & 29.4 & 8.3 & -1.3 & 1.6 & -.1 & 8.5 \\
\hline $\begin{array}{l}\text { and upward-moving } \\
\text { deep percolation }\end{array}$ & 12.8 & 3.6 & -.6 & .2 & 6 & 3.8 \\
\hline Total & 91.9 & 25.8 & -4.2 & 3.0 & -3.8 & 20.8 \\
\hline
\end{tabular}

contribute mostly to drainflow, and recharge to the saturated zone is assumed to contribute mostly to drainflow and bare-soil evaporation (evaporation occurs at the water table, whereas ground-water flow to the drainage systems can occur at substantial depths below the water table). Hence, the groundwater component of drainflow in each subarea is the sum of lateral ground-water flow and upward-moving deep percolation. For example, lateral ground-water flow into the subarea that intercepts upward-moving deep percolation is actually ground water originating at the bottom model layer but in areas slightly upslope of the affected area. Lateral ground-water flow in this subarea is therefore considered upwardmoving deep percolation relative to the water budget calculated for the drained area. The resulting budget calculations indicate a net lateral flow of ground water into the drainage systems $\left(1.5 \times 10^{6} \mathrm{~m}^{3} / \mathrm{y}\right)$, and a net flow of upward-moving deep percolation into the drainage systems $\left(0.8 \times 10^{6} \mathrm{~m}^{3} / \mathrm{y}\right)$. Although most (89 percent) of the drainflow in the study area originates as recharge to the saturated zone within the drained area $\left(18.5 \times 10^{6} \mathrm{~m}^{3} / \mathrm{y}\right)$, the contribution of regional ground water to total drainflow is significant (about 11 percent of the drainflow is lateral ground-water flow and upward-moving deep percolation).
Figure 19 shows the recharge areas for the lateral flowing ground-water component that contributes to drainflow. Most of this water originates as recharge to the saturated zone in undrained areas upslope of the drainage systems. The horizontal displacement of this recharge along simulated ground-water flow paths ranges from 0.3 to $3.6 \mathrm{~km}$ and requires from 10 to 90 years to reach the downslope drainage systems, respectively. The simulated traveltimes generally agree with tritium data reported by John Fio and David Leighton (U.S. Geological Survey, in press., 1994) and qualitatively confirm results of the flow model and particle-tracking simulations. Recharge to the saturated zone in areas bordered in the west by the ground-water divide (fig. 13) and the east by the recharge areas shown in figure 19 presumably moves along deeper flow paths. These deep flow paths probably extend beneath the lower model layer and become upward-moving deep percolation in the drained area, resulting in upward-moving deep percolation in the water budget. Ground water moving along these deep flow paths travel distances substantially greater than $3.6 \mathrm{~km}$ and require traveltimes that probably are longer than 90 years. 


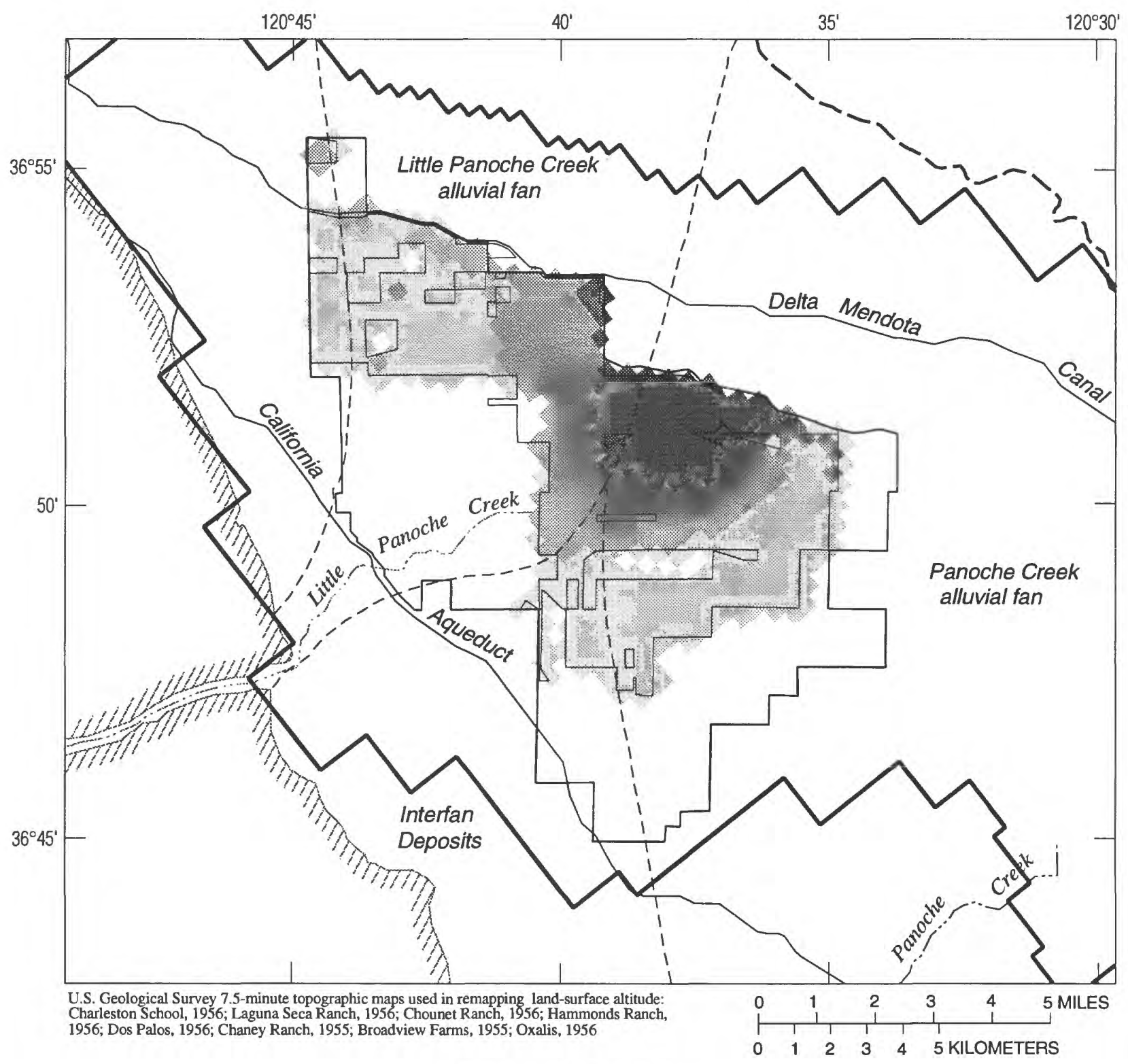

E X P L A N A T I O N

CONTRIBUTING SOURCES TO DRAINFLOW

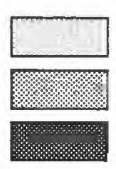

Recharge to the saturated zone

Recharge and lateral flowing ground water

Recharge and upward-moving deep percolation

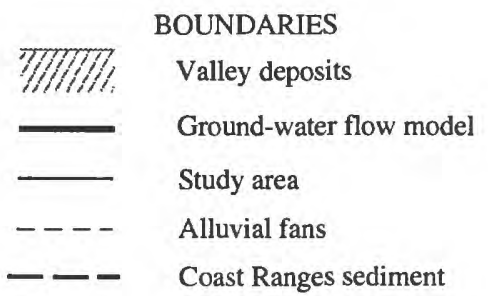

Figure 18. Delineation of drainage systems that intercept mostly recharge to the saturated zone, lateral ground-water flow, and upward-moving deep percolation in part of the western San Joaquin Valley. 


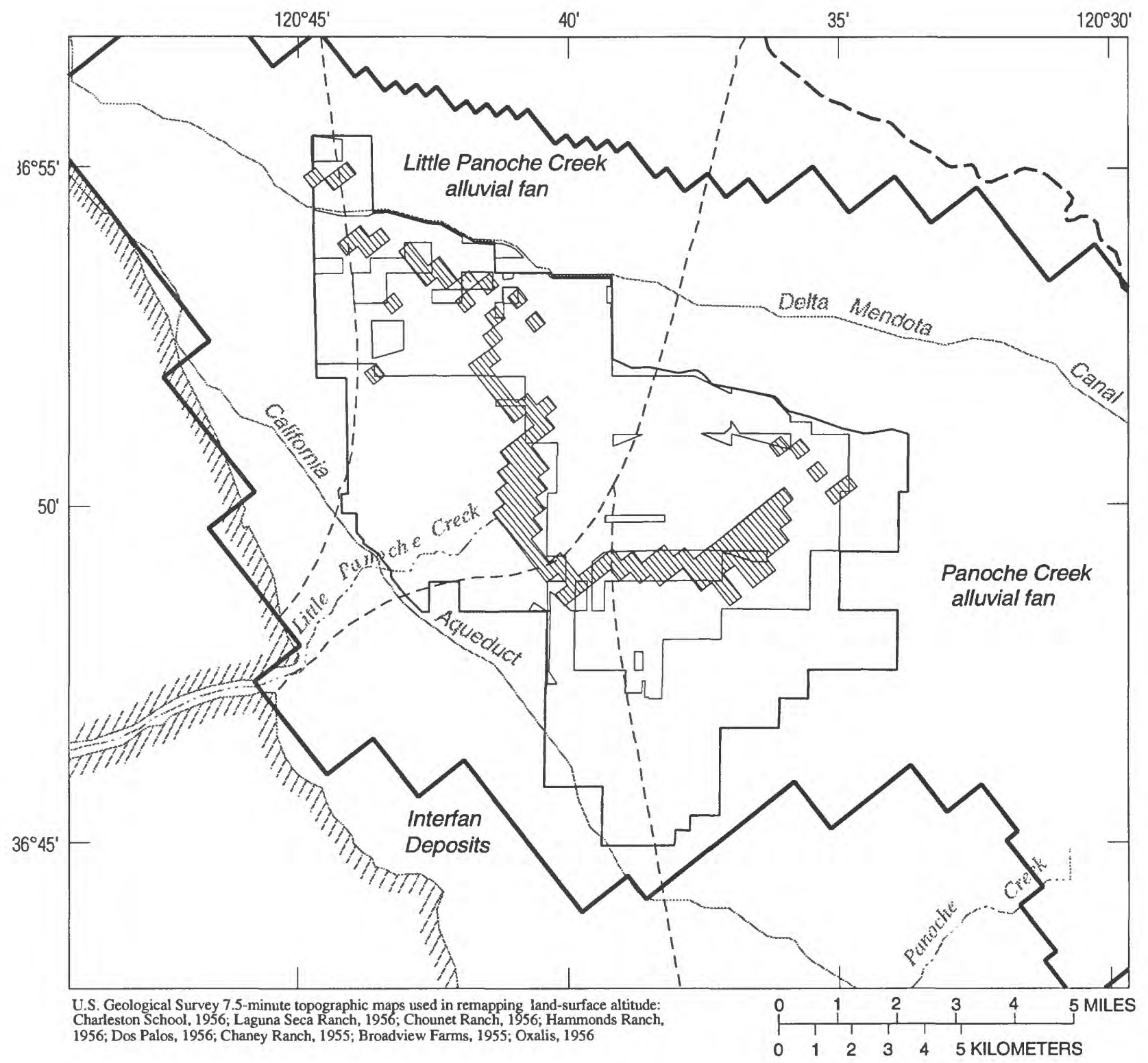

EX P L A N A T I O N

RECHARGE AREAS FOR LATERAL GROUND-WATER FLOW INTERCEPTED BY DOWNSLOPE DRAINAGE SYSTEMS

BOUNDARIES

T/1/1/1/i/, Valley deposits

$\begin{array}{ll}\longrightarrow \quad \text { Ground-water flow model } \\ & \text { Study area }\end{array}$

- - - Alluvial fans

- Coast Ranges sediment

Figure 19. Recharge areas contributing to lateral ground-water flow and downslope drainflow in part of the western San Joaquin Valley. 


\section{SENSITIVITY OF THE WATER BUDGET COMPONENTS TO SIMULATED HYDROLOGIC CONDITIONS}

Changes in irrigation technology and water-use practices will alter future hydrologic conditions in the western San Joaquin Valley. For example: increases in irrigation efficiency will decrease recharge to the saturated zone, and greater rates of pumping will result in increased deep percolation (Belitz and others, 1992). Changes to the quantity and distribution of drainflow as a consequence of these activities may vary on a field-by-field basis, and their simulation and prediction require accurate specification of drainflow conductance terms in the flow model. The sensitivity of the model and simulated water budget was, therefore, assessed. Specifically, the model was tested for reductions in recharge to the saturated zone, increases in deep percolation caused by pumping, and variations in drain conductance terms.

\section{REDUCING RECHARGE TO THE SATURATED ZONE}

Improvements to irrigation technology and application practices will reduce the quantity of applied water percolating past the plant root zone and recharging the saturated zone. The sensitivity of the water budget to changes in recharge was tested by adjusting the values of specified recharge to the saturated zone. Results indicate that simulated heads and drainflow were most sensitive to recharge in the drained area, and a trial-and-error approach indicates that minimum heads and drainflow were obtained when recharge to the saturated zone was zero in the entire study area. A condition of zero recharge does not necessarily imply nonirrigated conditions, but can indicate conditions of no net movement of irrigation water across the water table. Under these conditions, the simulated water table and drainflow were maintained by the hydraulic-head surface of the generalhead boundary and lateral ground-water flow that originated as irrigation water applied to fields upslope from the study area.

The simulated water budget for the condition of zero recharge (table 5) shows that drainflow in the absence of recharge was 86 percent less than reported in table 3 . The model indicates a net movement into the drained area of $2.4 \times 10^{6} \mathrm{~m}^{3} / \mathrm{y}$ by laterally flowing ground water and $0.5 \times 10^{6} \mathrm{~m}^{3} / \mathrm{y}$ by upward-moving deep percolation. Assuming that upward-moving deep percolation is intercepted by the drainage systems, 82 percent of the drainflow was from lateral flows $\left(2.3 \times 10^{6} \mathrm{~m}^{3} / \mathrm{y}\right)$ and 18 percent was from upwardmoving deep percolation. The application of these results is limited because the model does not simulate changes in hydraulic head beneath the lower model boundary that could occur from alterations in recharge conditions upslope of the drainage systems. Additional data and model revision would be necessary to simulate greater depth intervals of the aquifer in order to quantify the hydraulic connection between upslope recharge and downslope drainflow. This can be accomplished by collecting additional texture and hydraulic head data for depths below the lower model layer and from areas upslope of the study area. Incorporation of this information into the model by modification of its physical boundaries will more accurately simulate the sensitivity of drainflows to recharge within and upslope of the drainage systems.

Table 5. Simulated water budget for three subareas for conditions of zero recharge to the saturated zone

[Positive quantities represent additions to the water budget and drainflow, whereas negative quantities represent subtractions from the water budget and reductions to drainflow. $\mathrm{km}^{2}$, square kilometer]

\begin{tabular}{|c|c|c|c|c|c|c|}
\hline \multirow[b]{2}{*}{$\begin{array}{l}\text { Average depth } \\
\text { to water table }\end{array}$} & \multirow[b]{2}{*}{$\begin{array}{c}\text { Area } \\
\left(\mathrm{km}^{2}\right)\end{array}$} & \multicolumn{5}{|c|}{ Values in millions of cubic meters per year } \\
\hline & & $\begin{array}{l}\text { Recharge to the } \\
\text { saturated zone } \\
(R)\end{array}$ & $\begin{array}{l}\text { Bare-soil } \\
\text { evaporation } \\
(E)\end{array}$ & $\begin{array}{l}\text { Lateral ground- } \\
\text { water flow } \\
(G l)\end{array}$ & $\begin{array}{c}\text { Deep } \\
\text { percolation } \\
(D p)\end{array}$ & $\begin{array}{l}\text { Drain- } \\
\text { flow } \\
(Q d)\end{array}$ \\
\hline Greater than 3 meters & 36.0 & 0 & 0 & 3.0 & -3.0 & 0 \\
\hline \multicolumn{7}{|c|}{ Less than or equal to 3 meters } \\
\hline Undrained & 33.5 & 0 & -.1 & -2.7 & 2.8 & 0 \\
\hline Drained & 91.9 & 0 & -.1 & 2.4 & .5 & 2.8 \\
\hline Total & 161.4 & 0 & -.2 & 2.7 & .3 & 2.8 \\
\hline
\end{tabular}


INCREASING DEEP PERCOLATION WITH INCREASED PUMPING

Increasing pumping can increase vertical hydraulic-head gradients between the water table and hydraulic heads at greater depths. Simulations made using the regional model indicate that pumping affects hydraulic heads at depths corresponding to the general-head boundary. For example, after 2 years of pumping at $0.14 \mathrm{~m} / \mathrm{y}$, the average decreases in head simulated by the regional model were $0.4 \mathrm{~m}$ beneath areas having an average depth to the water table greater than $3 \mathrm{~m}$ below land surface, $0.6 \mathrm{~m}$ beneath undrained areas where the average depth to the water table is within $3 \mathrm{~m}$ of land surface, and $1.1 \mathrm{~m}$ beneath the drained areas (Steven Phillips, U.S. Geological Survey, written commun., 1991). The sensitivity of the water budget to the effects of pumping and deep percolation was assessed in this study by adjusting the prescribed heads of the general-head boundaries as indicated by regional model simulations. The resulting water budget (table 6) shows a 20-percent reduction in simulated drainflow and a 26-percent increase in deep percolation from the results reported in table 3. The particle-tracking results indicate that most of the lateral flow into the drained area becomes deep percolation, and consequently most of the drainflow is recharge applied to the fields above the drainage systems (results not shown).

Drainflow quantity can be altered substantially by increasing deep percolation, but the results reported for this study are a consequence of hydrologic changes by pumping simulated by the regional flow model. The regional model simulates pumping as a distributed sink, when in reality pumping removes water from specific locations and depth intervals in the aquifer. The hydraulic response to pumping could significantly differ between fields near pumping wells when compared to those at greater distances. Therefore, additional work is necessary in order to specify the location, magnitude, and depth distribution of ground-water pumping in the study area. This will require modification of the model boundaries to simulate greater depths of the aquifer in order to include the deeper pumping zones and allow explicit simulation of pumping by the model.

\section{SPECIFICATION OF DRAINFLOW CONDUCTANCE TERMS}

The sensitivity of simulated drainflow to drain conductance was assessed using three model runs. In the first run, it was assumed that drain conductance, and therefore the effective hydraulic conductivity of the drain/aquifer system, is independent of drainlateral density, and thus, constant in the model. Drain conductance in this model run was equal to the value used in the regional model $\left(0.6 \times 10^{6} \mathrm{~m}^{2} / \mathrm{y}\right.$ per $2.59 \mathrm{~km}^{2}$ area of simulated drainage system). The second model run assumed that drain conductance is proportional to drain-lateral density, and the distribution of drain conductance used was the same as previous model runs. The third model run also assumed drain conductance is proportional to drainlateral density, but effective hydraulic conductivity of the drain/aquifer system is different for drainage systems on the Little Panoche and Panoche Creek fans. A trial-and-error approach was used to reproduce measured on-farm drainflows from fields on the two fans by incrementally adjusting effective hydraulic conductivity for two areas delineated by the alluvial fan boundaries. The best match was obtained

Table 6. Simulated water budget for three subareas for conditions of increased deep percolation as a result of increased pumping

[Positive quantities represent additions to the water budget and drainflow, whereas negative quantities represent subtractions from the water budget and reductions to drainflow. $\mathrm{km}^{2}$, square kilometer]

\begin{tabular}{|c|c|c|c|c|c|c|}
\hline \multirow[b]{2}{*}{$\begin{array}{l}\text { Average depth } \\
\text { to water table }\end{array}$} & \multirow[b]{2}{*}{$\begin{array}{l}\text { Area } \\
\left(\mathrm{km}^{2}\right)\end{array}$} & \multicolumn{5}{|c|}{ Values in millions of cubic meters per year } \\
\hline & & $\begin{array}{l}\text { Recharge to the } \\
\text { saturated zone } \\
(R)\end{array}$ & $\begin{array}{c}\text { Bare-soil } \\
\text { evaporation } \\
(E) \\
\end{array}$ & $\begin{array}{l}\text { Lateral ground- } \\
\text { water flow } \\
(G l)\end{array}$ & $\begin{array}{c}\text { Deep } \\
\text { percolation } \\
(D p)\end{array}$ & $\begin{array}{l}\text { Drain- } \\
\text { flow } \\
(Q d) \\
\end{array}$ \\
\hline Greater than 3 meters & 36.0 & 15.1 & 0 & 2.2 & -17.3 & 0 \\
\hline \multicolumn{7}{|c|}{ Less than or equal to 3 meters } \\
\hline Undrained $\ldots \ldots$ & 33.5 & 14.7 & -5.3 & -4.0 & -5.4 & 0 \\
\hline Drained & 91.9 & 25.8 & -3.1 & 3.9 & -10.0 & 16.6 \\
\hline Total & 161.4 & 55.6 & -8.4 & 2.1 & -32.7 & 16.6 \\
\hline
\end{tabular}


Table 7. Model results using three distributions of drain conductance

[Correlation coefficient $\left(r^{2}\right)$ calculated from comparison of simulated drainflow and measured flow results from flowmeter and power-consumption data. RMSE, root mean square error; BIAS, bias. $\mathrm{km}^{2}$, square kilometer; $\mathrm{m}^{3} / \mathrm{y}$, cubic meter per year; $\mathrm{m}$, meter; $\mathrm{m}^{2} / \mathrm{y}$, square meter per year; --, no data]

\begin{tabular}{|c|c|c|c|c|c|c|}
\hline \multirow[b]{2}{*}{$\begin{array}{l}\text { Drain conductance } \\
\text { used in model }\end{array}$} & \multirow{2}{*}{$\begin{array}{c}\text { Average drain } \\
\text { conductance value } \\
\text { per } \mathrm{km}^{2} \\
\text { area }\left(10^{6} \mathrm{~m}^{2} / \mathrm{y}\right)\end{array}$} & \multirow[b]{2}{*}{$\begin{array}{l}\mathrm{RMSE} \\
(\mathrm{m})\end{array}$} & \multirow[b]{2}{*}{$\begin{array}{c}\text { BIAS } \\
(\mathrm{m})\end{array}$} & \multicolumn{2}{|c|}{$\begin{array}{l}\text { Drainflow measured with } \\
\text { flowmeters and power } \\
\text { consumption data }\left(10^{6} \mathrm{~m}^{3} / \mathrm{y}\right)\end{array}$} & \multirow{2}{*}{$\begin{array}{c}r^{2} \\
\text { (percent) }\end{array}$} \\
\hline & & & & $\begin{array}{c}\text { Drainage systems } \\
\text { on the } \\
\text { Little Panoche } \\
\text { Creek fan }\end{array}$ & $\begin{array}{l}\text { Drainage } \\
\text { systems on } \\
\text { the Panoche } \\
\text { Creek fan }\end{array}$ & \\
\hline Regional model & 0.6 & 0.8 & -8.3 & 5.8 & 6.8 & 9 \\
\hline $\begin{array}{l}\text { Calculated from drain- } \\
\text { lateral density }\end{array}$ & .7 & .8 & -8.6 & 5.5 & 7.0 & 9 \\
\hline Trial-and-error & 1.5 & .9 & -10.2 & 6.6 & 2.6 & 34 \\
\hline Measured & -- & -- & -- & 6.8 & 2.7 & -- \\
\hline
\end{tabular}

using an effective hydraulic conductivity of $500 \mathrm{~m} / \mathrm{y}$ for drainage systems on the Little Panoche Creek fan and $6 \mathrm{~m} / \mathrm{y}$ for drainage systems on the Panoche Creek fan. As discussed previously, recharge to the saturated zone (specified in the model), drain-lateral density, and drainage-system location relative to the two fans explain about 40 percent of the measured spatial variability in annual drainflow.

Table 7 reports summary statistics for simulated heads (RMSE and BIAS), drainflow from the two fans (combined discharge from drainage systems having flowmeter and power-consumption data only), and correlation coefficient $\left(r^{2}\right)$ between corresponding measured and simulated drainflows. The trial-anderror approach most closely reproduces the spatial distribution of on-farm flows $\left(r^{2}=0.34\right)$; whereas, the other two models simulate substantially greater discharge from drainage systems on the Panoche Creek fan. Simulated heads generally were greater using the trial-and-error approach than in the other two model runs, and total drainflow for the study area simulated using the trial-and-error approach (not shown in table 7) was 24 percent less than measured $\left(15.8 \times 10^{6} \mathrm{~m}^{3} / \mathrm{y}\right)$. A discrepancy between measured and simulated drainflow for the entire study area indicates potential measurement errors when using the weirs or a need to modify drain conductance terms for model cells in areas outside the boundaries of the two fans, or both. Delineation of ground-water flow paths and analysis of the water budget for the trial-and-error model run (results not shown) indicate that 81 percent of the drainflow originated as recharge to the saturated zone in the drained area $\left(13.9 \times 10^{6} \mathrm{~m}^{3} / \mathrm{y}\right)$. The remaining flow consists of lateral-flowing ground water $\left(1.5 \times 10^{6} \mathrm{~m}^{3} / \mathrm{y}\right)$ and upward-moving deep percolation $\left(0.4 \times 10^{6} \mathrm{~m}^{3} / \mathrm{y}\right)$. Though the magnitude of recharge and ground-water components that contribute to drainflow generally are less using the trial-and-error approach than reported in table 3 , their proportional contribution to total simulated drainflow is about the same ( 88 and 12 percent, respectively).

Simulation of the measured variability in on-farm drainflow can be improved by better definition of drain conductance in the model. This can be done by improved quantification of the spatial variability in effective hydraulic conductivity of the drain/aquifer system. Additional work should focus on evaluating the variability in sediment texture and hydraulic conductivity between fields. Although not specifically tested and discussed in this section, better definition of drain-lateral altitudes also will improve the simulation of drainflow. Incorporation of this information into the model will enable more reliable prediction of drainflow response to future changes in hydrologic conditions.

\section{SUMMARY AND CONCLUSIONS}

A water budget was calculated for a part of the western San Joaquin Valley, California, to delineate contributing sources to on-farm drainflow. A ground- 
water flow model was used to calculate the water budget in order to include the contribution of regional ground-water flow to on-farm drainflow. The flow model was constructed from a conceptual framework developed from geohydrologic data collected during the period 1987 to 1991 , and the model was used to simulate average annual conditions represented by the data set.

Geohydrologic data indicate that ground-water flow directions are affected by the distribution of unconsolidated coarse- and fine-grained sediment. Predominantly coarse-grained sediment in the upslope areas result in substantial depths to the water table (greater than 3 meters below land surface), whereas in low-lying areas predominantly fine-grained sediments result in a water table within 3 meters of land surface. Vertical hydraulic-head gradients calculated between shallow and deep observation wells indicate that flow is downward in the upslope areas, but can be upward in the low-lying areas. The vertical component of flow changes with depth at some locations due to heterogeneity in subsurface lithology, ground-water withdrawals by drainage systems, the frequency and intensity of irrigation, and pumping.

Estimates of water applied, effective precipitation, and consumptive use by crops indicate that irrigation contributes $55.6 \times 10^{6}$ cubic meters per year of recharge to the saturated zone. The ground-water flow model and water budget analysis showed that $10.3 \times 10^{6}$ and $20.8 \times 10^{6}$ cubic meters per year of this recharge is removed by bare-soil evaporation and drainflow, respectively. About 89 percent of the drainflow originates as recharge within the fields that overlay the drainage systems, and 11 percent is lateral flowing ground-water and upward-moving deep percolation originating as recharge within fields upslope of the drainage systems. Although most of the drainflow originates as recharge to the saturated zone within the drained areas, the contribution of regional ground water is significant.

Changes in irrigation technology and water-use practices will alter ground-water flow characteristics and drainflow. For example, results of model simulation indicate that drainflow decreases by 86 percent in the absence of recharge to the saturated zone. Also, vertical gradients and deep percolation under current recharge conditions can be altered by pumping; a simulated pumping rate of 0.14 meters per year resulted in a 20-percent reduction in drainflow. The model is limited however by its physical boundaries, and greater depth intervals of the aquifer would have to be simulated to adequately quantify the effects of recharge and pumping on drainflow. Furthermore, improved specification of drainage system design and the effective hydraulic conductivity of the drain/ aquifer system is necessary to more accurately simulate spatial variability in drainflow. The results and conclusions from this study provide an important step towards the transfer of geohydrologic information to water managers and other decisionmakers trying to minimize the drainage problem in the western San Joaquin Valley.

\section{References Cited}

Ayars, J.E., and Schrale, Gerrit, 1989, Irrigation efficiency and regional subsurface drain flow on the west side of the San Joaquin Valley: Final Report on Contract B56488, submitted to California Department of Water Resources Office of Water Conservation, $120 \mathrm{p}$.

Belitz, Kenneth, and Heimes, F.J., 1990, Character and evolution of the ground-water flow system in the central part of the western San Joaquin Valley, California: U.S. Geological Survey Water-Supply Paper 2348, 28 p.

Belitz, Kenneth, and Phillips, S.P., 1992, Simulation of water-table response to management alternatives, central part of the western San Joaquin Valley, California: U.S. Geological Survey Water-Resources Investigations Report 91-4193, $41 \mathrm{p}$.

Belitz, Kenneth, Phillips, S.P., and Gronberg, J.M., 1992, Numerical simulation of ground-water flow in the central part of the western San Joaquin Valley, California: U.S. Geological Survey Water-Supply Paper 2396, $69 \mathrm{p}$.

Bull, W.B., and Miller, R.E., 1975, Land subsidence due to ground-water withdrawal in the Los Banos-Kettleman City area, California, Part 1. Changes in the hydrologic environment conducive to subsidence: U.S. Geological Survey Professional Paper 437-E, $71 \mathrm{p}$.

Deverel, S.J., and Fio, J.L., 1991, Ground-water flow and solute movement to drain laterals, western San Joaquin Valley, California. I. Geochemical assessment: Water Resources Research, v. 27, no. 9, p. 2233-2246.

Deverel, S.J., Gilliom, R.J., Fujii, Roger, Izbicki, J.A., and Fields, J.C., 1984, Areal distribution of selenium and other inorganic constituents in shallow ground water of the San Luis Drain service area, San Joaquin Valley, California: U.S. Geological Survey Water-Resources Investigations Report 84-4319, 67 p.

Fio, J.L., and Deverel, S.J., 1991, Groundwater flow and solute movement to drain laterals, western San Joaquin Valley, California. II. Quantitative hydrologic assessment: Water Resources Research, v. 27, no. 9, p. 2247-2257.

Gronberg, J.M., and Belitz, Kenneth, 1992, Estimation of a water budget for the central part of the western San Joaquin Valley, California: U.S. Geological Survey Water-Resources Investigations Report 91-4192, 22 p. 
Harbaugh, A.W., 1990, A computer program for calculating subregional water budgets using results from the U.S. Geological Survey modular threedimensional finite-difference ground-water flow model: U.S. Geological Survey Open-File Report 90-392, $46 \mathrm{p}$.

Johnson, A.I., Moston, R.P., and Morris, D.A., 1968, Physical and hydrologic properties of water-bearing deposits in subsiding areas in central California: U.S. Geological Survey Professional Paper 497-A, $71 \mathrm{p}$.

Laudon, Julie, and Belitz, Kenneth, 1991, Texture and depositional history of late Pleistocene-Holocene alluvium in the central part of the western San Joaquin Valley, California: Bulletin of the Association of Engineering Geologists, v. 28, no. 1, p. 73-88.

Leighton, D.A., Deverel, S.J., and Macdonald, J.K., 1992, Spatial distribution of selenium and other inorganic constituents in ground water underlying a drained agricultural field, western San Joaquin Valley, California: U.S. Geological Survey Water-Resources Investigations Report 91-4119, 73 p.

Lord, J.M., Incorporated, 1988, Innovative techniques to reduce subsurface drainage flows: A report prepared for the San Joaquin Valley Drainage Program, Sacramento, California, $27 \mathrm{p}$.

McDonald, M.G., and Harbaugh, A.W., 1988, A modular three-dimensional finite-difference ground-water flow model: U.S. Geological Survey Techniques of WaterResources Investigations, Book 6, Chap. A1, 576 p.

Nielson, D.R., Biggar, J.W., and Erh, K.T., 1973, Spatial variability of field measured soil-water properties: Hilgardia, v. 42, no. 7, p. 215-259.
Ohlendorf, H.M., Hothem, R.L., Bunck, C.M., Aldrich, T.W., and Moore, J.F., 1986, Relationships between selenium concentrations and avian reproduction:

North American Wildlife and Natural Resources Conference, 51st, Reno, Nevada, Transactions, 1986, p. 330-342.

Page, R.W., 1986, Geology of the fresh ground-water basin of the Central Valley, California: U.S. Geological Survey Professional Paper 1401-C, 54 p., 5 plates.

Phillips, S.P., and Belitz, Kenneth, 1991, Calibration of a texture-based model of a ground-water flow system, western San Joaquin Valley, California: Ground Water, v. 29 , no. 5, p. 702-715.

Pollock, D.W., 1988, Semianalytical computation of path lines for finite-difference models: Ground Water, v. 26 , no. 6 , p. $743-750$.

1989, Documentation of computer programs to compute and display pathlines using results from the U.S. Geological Survey modular three-dimensional finite-difference ground-water flow model: U.S. Geological Survey Open-File Report 89-381, 188 p.

Presser, T.S., and Barnes, Ivan, 1985, Selenium concentrations in waters tributary to and in the vicinity of the Kesterson National Wildlife Refuge, Fresno and Merced Counties, California: U.S. Geological Survey Water-Resources Investigations Report 85-4220, 73 p.

Rantz, S.E., compiler, 1969, Mean annual precipitation in the California Region: U.S. Geological Survey Open-File Report, scale 1:1,000,000, 2 sheets. (Reprinted 1972 and 1975).

Sampson, R.J., 1988, Surface III: Kansas Geological Survey, Lawrence, Kansas, 277 p. 